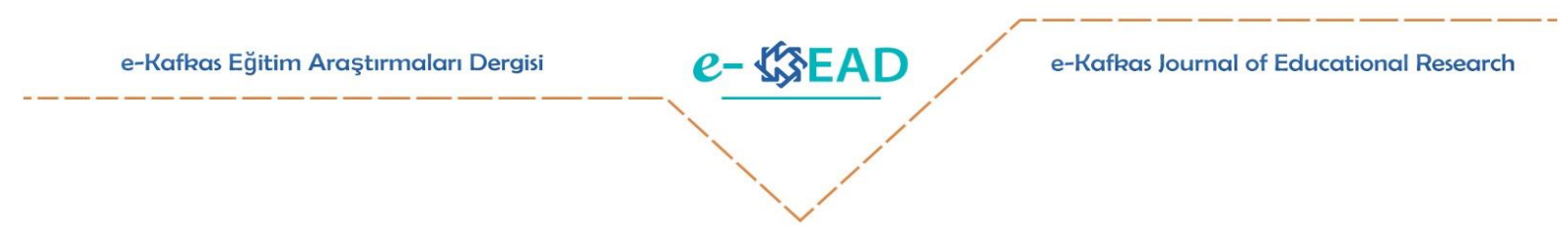

\title{
Öğrencilerin Toplumsal Köken Özellikleri ve İstenmeyen Davranışlar: Meslek Liselerinde Bir Durum Analizi ${ }^{1}$
}

\section{Hayriye Yeşil Aydoğan (iD Binali Tunç (D)}

Atıf: Aydoğan, Y. A. ve Tunç, B. (2020). Öğrencilerin toplumsal köken özellikleri ve istenmeyen davranışlar: Meslek liselerinde bir durum analizi. e-Kafkas Eğitim Araştırmaları Dergisi, 7, $185-206$. doi:10.30900/kafkasegt.750179

\section{Araştırma Makalesi}

Geliş Tarihi: 09.06.2020

$\ddot{O} \mathbf{z}$

Kabul Tarihi: 21.07 .2020

$\mathrm{Bu}$ araştırmanın amacı, eğitimci ve öğrenci görüşlerine dayalı olarak, mesleki-teknik liselerde yaşanan istenmeyen davranış sorunlarını öğrencilerin toplumsal köken özellikleri temelinde değerlendirmektir. Bu amaçla araştırmada, mesleki-teknik liselerde yaşanan istenmeyen davranışlar ailelerin eğitimsel, ekonomik, kültürel ve eğitim algısı ile ilişkilendirilmiştir. Araştırmanın eğitimde disiplin konulu araştırmaların genelinden ayrılan yönü, öğrencilerin istenmeyen davranışlarını okul dışı toplumsal koşullarla ilişkilendirmesidir. Çalışma, toplumsal köken özelliklerinin yarattığı yoksunluğun öğrencilerin istenmeyen davranışlarına nasıl yol açabildiğini eğitim bileşenlerinin gözünden ortaya koymaya çalıştı̆̆ından nitel araştırma desenine uygun düzenlenmiştir. Araştırmada Mersin ilindeki iki mesleki-teknik Anadolu lisesindeki üç yönetici, üç rehber öğretmen, beş branş öğretmeni ve 12 öğrenciyle yüz yüze görüş̧meler yapılmıştır. Görüşmelerde öne çıkan noktalara ilişkin betimsel düzeydeki analizler katılımcılardan doğrudan alıntılarla desteklenerek değerlendirmeler yapılmıştır. Araştırmada katılımcı ifadeleri öğrencilerin yoksun ailelerden geldiğini, istenmeyen davranışların büyük ölçüde yoksun yaşam koşullarından kaynaklı olduğunu göstermektedir. Katılımcılar, ekonomik güçlük yaşayan, eğitim düzeyi düşük, iletişimin zayıf olduğu ailelerden gelen çocukların daha fazla istenmeyen davranış sorunu yaşadıklarını dile getirmişlerdir. Öğrencilerin çok büyük kısmının mesleki-teknik liseye gelme motivasyonu kısa yoldan bir mesleki beceri kazanarak gelir elde edebilecek bir işe girmektir. Öğrenciler gereksinimlerini karşılamak için hırsızlık, arkadaşlarından zorla para alma, devamsızlık ve okul terki gibi davranışlara başvurmakta; bu davranışlarda ebeveynlerin kendi sorunlarıyla ilgilenirken çocuklarını ihmal etmelerinin önemli bir payı olmaktadır. Ailelerde özellikle baba figürü eğitimsel tercihlerde belirleyici olurken annelerin çocuklarına ilişkin kararlarda etkisi sınırlıdır. Yine birçok aile çocuklarının gelir elde etmelerine ihtiyaç duyduklarından bazı zamanlarda çocuklarını okula göndermek yerine yevmiyeli işlere göndermektedirler.

Anahtar Sözcükler: Disiplin, istenmeyen davranışlar, öğrenci sosyo-ekonomik özellikleri

\section{Abstract}

This research aims to evaluate the problem behaviors in vocational-technical high schools on the basis of socioeconomic characteristics of students. Problem behaviors mostly have been associated with the educational, economic, cultural, and educational status of families. The aspect of the research does not consider the discipline problems of students as individuals and in-school situation. The study is organized in accordance with the qualitative research pattern as it tries to reveal how the deprivation created by socio-economic origin can lead to students' problem behavior. In the research, face-to-face interviews were held with three administrators, three guidance teachers, five branch teachers, and twelve students in two vocational-technical high schools in Mersin province. Most of the problem behaviors are largely due to disadvantaged living conditions. The participants stated that the students have disadvantaged economic and education conditions, and poor communication have more disciplinary problems. The motivation of the vast majority of students coming to vocational-technical high school is to enter a job that can earn income by gaining a professional skill shortly. Students behaviors such as theft, forced money from their friends, absenteeism, and drop-outs in order to meet their some basic needs. While families are dealing with their main problems, they neglect their children. While fathers are determinant in educational preferences in families, the effect of mothers on decisions about their children is limited. Many families also send their children to casual jobs instead of sending them to schools because they need their children to earn income.

Keywords: Discipline, undesirable behaviors, student socioeconomic characteristics

\footnotetext{
${ }^{1}$ Bu çalışma birinci yazarın "mesleki teknik lise öğrencilerinin disiplin sorunlarının toplumsal kökenlerine ilişkin bir çözümleme" isimli yüksek lisans tezinden üretilmiştir.
} 


\section{Giriş}

Eğitim konusu gündeme geldiğinde ilk dile getirilen konulardan biri “okulda disiplin"dir. Disiplin konusundaki çalışmalar, istenmeyen davranışların meslek liselerinde görece daha fazla yaşandığını göstermektedir. Yine araştırmalar meslek liselerinin dünyanın birçok ülkesinde olduğu gibi Türkiye'de de akademik başarı yönünden düşük ve sosyo-ekonomik olarak yoksul öğrencilerin devam ettiği bir okul türü olduğunu (Bülbül, 2012; Fındık ve Kavak, 2013; Tunç, 2011; Tunç, Yıldız ve Doğan, 2015; Vuranok, Özcan ve Çelebi, 2017) ortaya koymaktadır. Meslek liselerinde disiplin sorunlarının görece fazla olmasının yanında öğrencilerin yoksul ailelerden gelmeleri, öğrencilerin istenmeyen davranışları ile toplumsal kökenleri arasındaki bağlantıya işaret etmektedir.

Disiplin konulu akademik çalışmalarda istenmeyen davranışların tanımlanması, nedenleri ve çözüm önerileri üzerinde durulurken konunun sosyo-ekonomik boyutu fazla ele alınmamaktadır. Bir başka ifadeyle okuldaki istenmeyen davranış sorunlarının toplumsal boyutu gözardı edilirken ailenin ve sosyal çevrenin öğrenci davranışları üzerindeki etkisi ihmal edilmektedir. Dezavantajlı çevreden gelen öğrencilerde ve dezavantajlı yerleşim alanlarındaki okullarda istenmeyen davranışlar görece daha fazla yaşanmaktadır (Tunç, Yıldız ve Doğan, 2015). Bununla birlikte, Türkçe ve yabancı dildeki kaynaklarda konunun birçok değişkenle ele alınmasına karşın istenmeyen davranışların toplumsal kökenle ilişkisine yönelik araştırmaların sınırlı sayıda olması konunun tüm yönleriyle anlaşılmasını da güçleştirmektedir. $\mathrm{Bu}$ nedenle araştırmada istenmeyen davranışların toplumsal kökenlerinin daha iyi anlaşılabileceği meslek liseleri araştırma birimi olarak alınmıştır. İstenmeyen davranışların toplumsal kökenlerine yönelik inceleme, istenmeyen davranışların okulda başlayan ve çözümünün okulda aranması gereken bir olgu olarak kabul edildiği geleneksel bakış açısını aşarak konuyu toplumsal bir bağlama oturtacaktır. Öğrencilerin toplumsal köken özellikleri ile okulda yaşanan istenmeyen davranışların ilişkisini ortaya koymanın görünenin ötesinde, disiplin sorunu olarak atfettiğimiz şeylerin temelinde sosyo-ekonomik faktörlerin de rol oynadığının farkına varılmasını sağlayacağı ve bu bakış açısıyla eğitimcilerin öğrencilere yaklaşımında ve istenmeyen davranışlar karşısındaki tutumlarında farklılık yaratacağı düşünülmektedir.

\section{Disiplin: Kavramsal Çerçeve}

Disiplin, olumlu olduğu kadar olumsuz anlamlar da yüklenen bir kavramdır. Bunun nedeni disiplinin insan davranışlarına müdahale edici yönüdür. İnsanların davranışlarının benzeşmesi gerektiğini, toplumsal yaşamın bunu gerektirdiğini düşünenler disipline olumlu bakarken; insan davranışlarına dışarıdan yapılan her müdahalenin insan iradesini sınırlandırdığını vurgulayanlar ise disipline eleştirel bakmaktadırlar. Bu görüş ayrılığı toplumsal birlikteliği sağlamada kullanılabilecek usul, araç ve mekanizmalar bakımından olmaktadır. Toplumsal birlikteliğin insan davranışlarına müdahale edilerek mi yoksa davranışların bireylerin iradesine bırakılarak mı sağlanabileceği konusunda tartışmalar sürmektedir.

İnsan davranışlarının disipline edilmesini savunanlar davranışlara ilişkin kurallara odaklanırlar. Birçok kaynakta disiplin ve kural koyma ilişkisi vurgulanmıştır. Cemaloğlu (2007), Çiftçi (2008), Kök (2007), Erzurum ve Kır (2011) disiplini belirli amaçlar için bir araya gelmiş insanların düzen içinde yaşamasını sağlamak amacıyla toplumsal anlamda mevcut yasa, kural, ilke ve düzene uygun davranma zorunluluğu olarak tanımlamaktadırlar. Beş yazarın paylaştığı nokta ortak yaşamın olumlu ve istenilen ölçülerde devam edebilmesi için yürürlükteki her türlü toplumsal ve hukuksal kurala uyma zorunluluğudur. $\mathrm{Bu}$ düşünceyi paylaşanlar disiplinin olmaması halinde ortaya çıkabilecek toplumsal belirsizlik (kaotik) durumlarını ön plana çıkarırlar. Kaotik durumların güçsüzlerin aleyhine olabileceği, bu bakımdan haksızlığa uğrayanların korunmasının disiplinin bir işlevi olduğu dile getirilir. $\mathrm{Bu}$ perspektiften disiplin toplumsal eşitsizlik durumlarında güçsüzlerin lehine işleyen bir olgudur. Celep (2000) disiplini başkaları tarafından işbirliğine kapalı, saldırgan ya da diğer engelleyici tepkilere maruz kalmış insanların haklarını korumaya yönelik bir araç olarak görür.

Disipline bireylerin iradesinin sınırlandırılması bakımından eleştirel bakanlar aynı zamanda kurallara da eleştirel yaklaşırlar. Bunlara göre toplumsal kuralların çoğu alt toplumsal sınıfların denetim ve kontrolünü amaçlar. Kurala uyma Eggleton'a (2001) göre zihinsel veya ahlaki özellikleri düzelten, kalıba sokan ya da mükemmelleştiren, yetki ve kurallara itaati sağlayan, olumsuz davranışları cezalandırarak düzeltmeyi öngören bir "eğitme" sürecidir. Benzer şekilde insanların denetimine vurgu 
yapan İpek (2012) disiplinin, toplumsal gövdedeki unsurları ve bireyleri denetlemeyi sağlayan bir iktidar mekanizması yaratıı̆ını ifade eder.

Alanyazında, öğrencilerin disiplin altında tutulmasını savunanlar ağırlıktadır. Bu görüşte olanlara göre öğrenmenin gerçekleşmesinin ön koşulu çocukların davranışlarını kontrol altına alarak istenmeyen davranışları ortadan kaldırmaktır. Disiplin eğitim-öğretim sürecinin vazgeçilmez bir parçası ve etkili öğretimin yoludur. Bu yaklaşımı savunanlardan biri olan Babaoğlan'a (2009) göre disiplin eğitimin en faydalı ancak en zor yanı olmasının yanında etkili bir öğretim disiplin olmadan gerçekleşemez. Karataş'a (2008) göre disiplin çocuğa istenilen davranış ve alışkanlıkları öğretmek, kendi kendini denetleme ya da iç denetim demek olan ahlak gelişimini sağlamaktır. Kılıç'ın (2009) vurguladığı gibi temel amaç, öğrenciye istenen davranışları değerlendirme alışkanlı̆̆ kazandırmaktır. Bu aynı zamanda Çiftçi'nin de (2008) vurguladığı gibi disiplinin amacı demokratik anlayışa sahip, insancıl, uyumlu, başarılı ve aktif bireyler yetiştirmektir.

Alderman (2001) da Latinceden gelen disiplin sözcüğünün, aslında öğretim anlamına geldiğini ifade eder ve disiplini daha çok öğretim ile ilişkilendirir. Disiplin, öğrenme için uygun bir ortamın sağlanmasına aracılık eder. Arıcak $(2005 ; 2011)$ da disiplinin, öğretmenin sınıfta etkili öğrenme ortamı oluşturabilmesinin önemli bir aracı olduğunu, sınıftaki disiplinin öğrenme süreci ve kalitesini etkilediğini vurgular. Arıcak'a göre toplumda otorite figürü olduğu ve ondan korkulduğu sürece, bireyler kontrol altında tutulabilmekte, otorite kaynağ 1 veya korkusu olmadığında bireyler kontrollerini kaybedebilmektedirler. Öğretmen, Gürsel'in (2012) de vurguladığı gibi, öğrenciye hangi davranışın istenilir olduğunu gösterip öğretmek, öğrencinin bu davranışı yapıp yapmadığını izlemek, davranışı beklenenden iyi yaptığında ödüllendirmek, yapmadığında da onu cezalandırmakla sorumludur. Bu görüş eğitimde disiplini ceza ve ödül ile bağdaştırmaktadır. Yıldırım ve Aktepe'ye (2004) göre disiplin sanıldığ gibi zorlama, baskı altına alma, ceza verme anlamlarına gelmemekte, eğitim, öğretim, bir işi uygun kurallarıyla yapmayı öğrenme, uygun biçimde yaparak başarma anlamı taşımaktadır.

Eğitimde disipline eleştirel yaklaşan ve disiplinin olumsuz yanlarına dikkat çeken çalışmaları kendi içinde ikiye ayırmak olanaklıdır. Bunlardan birinci grupta yer alanlar disiplin olgusundan çok, biçimsel yönüne ve çocuklara uygulanmasına karşıdırlar. Bu çerçevede, Başar (2007), disiplinin kendi kararlarını veremeyecek eğitim düzeyi düşük insanlar için ara sıra gerekebileceğini fakat disiplinin olmaması gereken yerlerin başında okulların geldiğini savunur. Disiplin uygulamaları, çocukların zihinsel ve fiziksel gelişimine katı sınırlar getirerek onların gelişimini engelleyebileceği gibi, korku ve kayg1 öğrencilerin yaratıcılığını, farklı düşünmelerini engelleyebilir. Eğitimdeki disiplinin yarattığ1 olumsuz sonuçlara dikkat çekmek isteyen Gordon (2000) da evde ve okulda disiplin sağlamanın en zor yolunun çocukları disiplin altına almaya çalışmak olduğunu ve cezanın çocukta şiddet duygusunu ve saldırgan tutumu ortaya çıkardığını belirtir. Benzer şekilde Yıldırım (2010) da disiplinin baskı ve otoriteyi çağrıştırmasının bireylerde kendini yönetememe, başkalarının yönlendirmesine ve zorlamasına ihtiyaç duyma ve davranışlarını kontrol etmek için yeterli olmadığı inancına yol açtığını belirtir.

Disipline eleştirel yaklaşan kimi çalışmalar ise eğitimsel disiplini toplumsal disiplinin bir boyutu olarak eleştirirler. $\mathrm{Bu}$ görüşte olanlar eğitimin bireylerde istendik davranışlar oluşturma amacının bilinenin aksine hegemonik toplumsal yapının yeni kuşaklara benimsetilmesi olarak görürler. Eğitim, devlet ideolojisine uyumlu insan yetiştirme ve toplumsal itaati yeniden üretme sürecidir. Eğitim sayesinde insanların davranışları ve düşünceleri genel ahlakla ve kanunlarla uyumlulaştırılırken gönüllülük ve ikna yollarıyla olması gereken toplumsal rıza, zorunlulukla ve dayatmayla gerçekleştirilir (Çetin, 2001). Benzer şekilde disiplin ile tek tip bireyler oluşturulmasına dikkat çeken Temir (2013) ise tarihsel olarak disiplinin bireyin davranışlarını liderin/ustanın/öğretmenin görüşleri ve standartlarıyla uyumlu hale getirmek olduğunu belirtir. Dolayısıyla bireylerin belli kurallar etrafında davranışlarının denetlenmesinin nedenlerinden birinin bireyleri kontrol altına alma amac1 olduğu söylenebilir. Foucault'ya (1992) göre disiplin terbiye etme görevini yerine getirir. $\mathrm{Bu}$, otoritenin istenmeyen durumlar karşısında fiziksel bir şiddet uygulamaktansa onları uyumlu hale getirme stratejisinin de bir parçasıdır (Özsöz, 2014). Özellikle okullarda bireyleri disipline etmek için kategorik sınıflandırmalarla (başarıl1-başarısız, normal-anormal, sorunlu-sorunsuz, tehlikeli-zararsız vb.) bireylerin kim olduğu, nerede bulunması gerektiği ve nasıl bir kontrol altında tutulması gerektiği belirlenir (İpek, 2012). 
Diğer yandan okulların bireyleri disipline alarak uysal bedenler yetiştirmenin yanı sıra mevcut yapılanmayı koruduğuna dair görüşler de vardır. Okul sistemi birbirine eşit olmayan kültürel sermayeyle donanmış öğrenciler arasındaki farkı koruyarak kültürel sermayeye sahip olanlarla olmayanları birbirinden ayrıştırıcı bir işlev görür (Buyruk, 2009). Akademik başarısı düşük, disiplin sorunlarının görece fazla yaşandığı okulların çoğunlukla dezavantajlı sosyo-ekonomik çevrelerde olması gibi okullarda "suçlanan" öğrencilerin de çoğunlukla dezavantajlı toplumsal kökenli olması toplumsal eşitsizliklere işaret eder (Tunç, Yıldız ve Doğan, 2015). Thrup'ın (1998) da altını çizdiği gibi sosyal ve politik koşulların okul başarısı üzerindeki olası etkisinin tartışılmaması, sosyo-politik eşitsizliklerden kaynaklanan sorunların veya başarısızlıkların sorumluluğunun okullara yüklenmesine yol açar.

\section{Okulda İstenmeyen Davranışlar ve Toplumsal Köken İliş̧kisi}

Okullarda istenmeyen davranışlar bütün dünyada olduğu gibi Türkiye'de de önemli ve üstesinden gelinmesi gereken öncelikli konulardan biri olarak görülmektedir. Olumsuz öğrenci davranışlarının tek sorumlusunun öğrenci olmadığı gerçeği, eğitimcilerin çoğunluğu tarafından kabul görmektedir (Erden, 2005). Okulda istenmeyen öğrenci davranışlarının önlenmesi ve azaltılması için öncelikle davranışların kaynakları anlaşılarak çözümün öğrenci ve okulla sınırlı kalmadan okulun yakın ve uzak çevresini kapsayan bir perspektiften hareket edilmelidir (Kılıç 2009). Ailedeki bireylerin kişilik yapıları, eğitim durumları, meslekleri, ruh ve beden sağlı̆̆ ilişkileri çocuğun kişilik gelişimini etkilemektedir (Düzgün, 2006). Ailelerin öğrenciler üzerinde olumlu etkileri olabileceği gibi olumsuz etkileri de olabilmektedir. Akpınar ve Özdaş (2013) okul ve ailenin özelliklerine ek olarak istenmeyen öğrenci davranışlarının eğitim programı, medya, öğretmen ve öğrenci başta olmak üzere okul içi ve dışına taşan boyutları bulunduğunu belirtirler.

Çocukların davranışlarının şekillendiği ilk kurum ailedir. Okul disiplininin yalnızca öğrenci, yönetici ve öğretmenlerle ilgili olmadığını ve öğrenciyi etkileyen etmenlerin öğrenci davranışları üzerinde etkili olduğunu ifade eden Sarpkaya'ya (2007) göre, ailevi ve toplumsal değerler, olanaklar ve rol modelleri gibi çeşitli özellikler, öğrenci davranışlarını etkilemekte ve dolayısıyla okul disiplininin önemli bileşenleri arasında yer almaktadır. Benzer şekilde Erden (2005) de ailenin kültürel özellikleri, eğitim durumu, ekonomik koşulları, çocukla ilgilenme düzeyi, çocuk sayısı gibi birçok etmenin çocuğun okuldaki davranışlarını etkilediğini belirtmektedir.

Aile ve toplumsal çevrenin öğrenci davranışları üzerindeki etkisini en fazla vurgulayan düşünürlerden biri Bourdieu'dur. Eğitimdeki başarı-başarısızlıkların, tercihlerin, olumlu-olumsuz davranışların kaynağı büyük ölçüde ailedir. Öğrenciler geldikleri sosyal çevreden edinmiş oldukları ön yatkınlık ve ön bilgiler bakımından birbirlerinden ayrılırlar. Toplumsal köken eğitimin geleceğini, kariyer tercihlerini ve bunların sonucu olan başarıyı veya eğitim basamaklarındaki elenme olasılıklarını da belirlemektedir (Bourdieu ve Passeron, 2015). Anne-babaların eğitim düzeyinin çocuğun okul algısını belirlediğini ifade eden Sarıbaş ve Babadağ (2015) çocukların eğitime devam etme şanslarının ailelerinin eğitim düzeyleriyle paralel olduğunu belirtirler. Dolayısıyla da eğitim düzeyi yüksek olan ailelerin çocukları daha yüksek konumlara gelirler.

Öğrencilerin toplumsal köken özelliklerinin öğrenci davranışları üzerindeki etkilerinin en fazla gözlendiği nokta akademik "başarı"dır. Öğrenci başarısı, öğrencilerin sosyo-ekonomik özellikleri ve kültürel sermayelerinden ayrı düşünülemez. Birçok araştırma eğitimsel başarı üzerinde ailevi ve toplumsal etkenlerin okul faktöründen daha etkili olduğunu ortaya koymaktadır (Buyruk, 2009). 2009 Uluslararası Öğrenci Başarısını Değerlendirme Programı (PISA) raporuna göre OECD ülkeleri arasında Türkiye düşük sosyo-ekonomik kökenin öğrenci başarısını en fazla etkilediği üçüncü ülkedir (Çelik, 2014).

Okullar görünen işlevinin yanında örtük şekilde öğrencilerin toplumsal sınıf özelliklerini yeniden üretme işlevi de üstlenirler. Bowles (1999) çocukların farklı okullara gitme eğilimlerinin ailede geliştirilen kişilik özellikleri, değerler ve beklentilere bağlı olduğunu ileri sürer. Okulların sosyoekonomik düzeyi yükseldikçe istenmeyen davranışların sayısı azalırken davranışların niteliği de farklılaşır. Diğer yandan okulların sosyo-ekonomik özellikleri düştükçe sorunların düzeyi de artar (Demirtaş, Üstüner ve Özer, 2007). Özellikle işçi sınıfına hitap eden meslek liseleri daha otoriter yöntemlerle çocukları yetiştirirken, üst sosyo-ekonomik konumdaki okulların ise akademik eğitime ağırlık vererek daha bağımsız öğrenciler yetiştirirler. Böylece toplumsal sınıfına uygun okullara giden 
öğrenciler benzer davranış kalıpları ile eğitim görürler (Kılıç, 2014). Willis'e göre işçi sınıfından gelen öğrencilerin giyim, mizah anlayışları, şiddet ve alkol kullanma davranışları okul otoritesine ve okulda hâkim orta sınıf kültürüne bir başkaldırıdır (Akt. Eskicumalı, 2003). Bu yönüyle istenmeyen davranışlar öğrencilere zorla benimsetilmeye çalış1lan kültüre karşı tepki olarak ortaya çıkan bir sonuçtur. Farklı çevrelerden gelen öğrencilerin kültürel özelliklerine bağlı olarak gösterdikleri davranışlar da farklılaşır.

İstenmeyen davranış tanımlaması öznel bir konudur. Öğretmenler arasında hangi davranışların istenir hangilerinin istenmeyen olduğu konusunda görüş birliği bulunmamaktadır. Önceki kısımda disiplin olgusuna ilişkin farklı bakış açıları dile getirilirken öğretmenlerin disiplin olgusuna bakış açılarının da farklılaştığı dile getirilmişti. Bozdoğan (2004) öğretmenlerin istenmeyen davranışları konusunda ortak bir ölçüte sahip olmadıklarını, bunun her öğretmenin kendi bakış açısına göre sorun olarak farklı davranışları göstermesinden kaynaklandığını ifade eder. Dolayısıyla bir öğretmen için istenen bir davranış bir diğer öğretmen için istenmeyebilir. Alanyazında farklı davranışlar dile getirilse de en fazla ortaklaşılan noktalar; temizlik ve görgü kurallarına uymama, kırıcı ve küfürlü konuşma, başkalarını rahatsız etme, dersi dinlememe, başkaları konuşurken konuşma, okula geç gelme, devamsızlık, sigara içmek, madde kullanımı, okula, arkadaşlarına ve eşyalara zarar verme, derse ilgisiz olma, edilgen davranışlar, verilen görevleri yapmama, öğretmenle çatışmaya girme, argo kullanımı, gürültü yapma, itaatsizlik, saldırganlık, düzensizlik, kılık kıyafete özen göstermeme, hırsızlık, okul kurallarına uymama, cep telefonu getirme (Başar, 2003; Ercan, 2009; Öztürk, 2004; Tunç, Yıldız ve Doğan, 2015) sayılmaktadır.

İstenmeyen öğrenci davranışları kuşkusuz her eğitim kademesinde karşılaşılan bir sorundur. Bu sorunun altında birçok etken yatmaktadır. Toplumsal köken özellikleri ise bunlardan biridir. Öğrencilerin sosyo-ekonomik özelliklerinin istenmeyen davranışlar üzerindeki etkisi bunların çözümünde ya da bu etkinin azaltılması konusunda neler yapılabileceği önemli bir tartışma konusudur. $\mathrm{Bu}$ anlamda araştırmada istenmeyen davranışlar toplumsal boyutu ile ele alınmaya çalışılmış ve öğrencilerin toplumsal köken özellikleri ile istenmeyen davranışlar arasındaki etkileşim, eğitim bileşenlerinin gözünden anlaşılmaya çalışılmıştır. Bu genel amaca ulaşmak için şu sorulara yanıt aranmıştır:

- Öğrencilerin eğitimsel yaşantılar ve toplumsal köken özellikleri nelerdir?

- Okullarda en sik yaşanan istenmeyen davranışlar nelerdir?

- İstenmeyen davranışların kaynakları nelerdir?

- İstenmeyen davranışların ortadan kaldırılması için neler yapılabilir?

\section{Yöntem}

$\mathrm{Bu}$ araştırmada, meslek liselerinde yaşanan istenmeyen davranış sorunlarının toplumsal kaynakları anlaşılmaya çalışılmaktadır. Araştırma, öğrencilerin istenmeyen davranışlarını, sahip oldukları toplumsal kökenleri bakımından derinlemesine anlamayı (Ritchie ve Lewis, 2013) amaçladığından, nitel araştırma desenine uygun düzenlenmiştir. Nitel çalışmalarda amaç, araştırma nesnesinin doğal ortamında yani yaşantı içinde deneyimleyenlerle görüşülerek, betimsel düzeyde açıklanmaya ve anlaşılmaya çalışılmasıdır. Bu sayede araştırmacının sınırlı müdahalesiyle deneyim sahibi katılımcıların duruma bakış açılarını, gözlem ve açıklamaları doğrudan alınabilmektedir. $\mathrm{Bu}$ sayede nitel araştırmalarda her bir katılımcı kendi deneyim ve ifadeleriyle araştırma konusunun genişlemesine, ayrıntılı anlaşılmasına, sürecin gelişimine dair deneyimlerini paylaşabilir. Araştırmada basit nitel çalışma stratejisi kullanılmıştır.

\section{Çalışma Evreni}

Araştırmanın çalışma evreni 2017 yılında Mersin il merkezinde ve ilçede bulunan iki meslek lisesinde öğrenim gören öğrenciler, bu okullarda görev yapan öğretmenler, rehber öğretmenler ve yöneticilerden oluşmaktadır. Araştırmada meslek liseleri disiplin sorunları konusunda görece diğer lise türlerine göre daha fazla gündeme geldikleri için araştırma birimi olarak alınmıştır. Ayrıca meslek lisesi öğrencilerinin büyük bölümü ekonomik ve kültürel sermaye (Bourdieu, 2015) bakımından yoksul ailelerden gelmektedir. Bu nedenlerle meslek liselerindeki eğitimciler ve öğrencilerin bu durumu daha fazla deneyimleme ve gözlemleme firsatı olabileceği düşünülmüştür. Katılımcı özellikleri Tablo 1'de yer almaktadir. 
Tablo 1.

$\underline{\text { Katılımcıların Kişisel Bilgileri }}$

\begin{tabular}{ll}
\hline Katılımcı Künyesi & Katılımcıların Özellikleri \\
\hline Öğrn.1 & Öğrenci, kadın,9.sınıf \\
Öğrn.2 & Öğrenci, kadın,9.sınıf \\
Öğrn.3 & Ögrrenci, erkek, 9.sınıf \\
Öğrn.4 & Öğrenci, erkek, 12.sınıf \\
Öğrn.5 & Öğrenci, erkek, 11.sınıf \\
Öğrn.6 & Öğrenci, kadın, 12.sınıf \\
Öğrn.7 & Öğrenci, kadın, 11.sınıf \\
Öğrn.8 & Öğrenci, erkek, 9.sınıf \\
Öğrn.9 & Öğrenci, kadın, 10.sınıf \\
Öğrn.10 & Öğrenci, kadın, 10.sınıf \\
Öğrn.11 & Öğrenci, erkek, 9.sınıf \\
Öğrn.12 & Ögrenci, erkek, 9.sınıf \\
M1 & Müdür yardımcıs1, erkek, edebiyat öğretmeni \\
M2 & Müdür yardımc1s1, kadı, İngilizce öğretmeni \\
M3 & Müdür yardımc1s1, erkek, meslek öğretmeni \\
Ö1 & Öğretmen, kadın, muhasebe öğretmeni \\
Ö2 & Öğretmen, kadın, muhasebe öğretmeni \\
Ö3 & Öğretmen, kadın, tarih öğretmeni \\
Ö4 & Öğretmen, erkek, ingilizce öğretmeni \\
R1 & Öğretmen, erkek, rehber öğretmen \\
R2 & Öğretmen, erkek, rehber öğretmen \\
R3 & Öğretmen, erkek, rehber öğretmen \\
\hline
\end{tabular}

Araştırmada katılımcılarda maksimum çeşitliliği sağlamak amacıyla farklı eğitim bileşenlerinin görüşlerine başvurulmuştur. Araştırmada üç yönetici, beş branş öğretmeni, üç rehber öğretmen ve 12 öğrenci ile yüzyüze görüşülmüştür. Okuldaki istenmeyen öğrenci davranışları hakkında yöneticiler ve rehber öğretmenlerin bilgisi olduğu, branş öğretmenlerinin ise sınıflarda yaşanan istenmeyen davranışlara doğrudan şahit oldukları düşünülmüştür. Ayrıca yönetici ve rehber öğretmenlerin okulda yaşanan istenmeyen davranışlarda öğretmen, öğrenci ve velilerle görüşme olanağı bulması bakımından olayların farklı açılardan anlaşılmasına katkı sağlayabileceği düşünülmüştür. Öğrencilerin ölçüt örneklem tekniğine uygun olarak farklı cinsiyet, bölüm ve sınıflardan olmalarına dikkat edilmiştir.

Görüşmelerin yapıldığı okullarda öğrenciler genel olarak kenar semtlerde yaşamını sürdüren, sosyo-ekonomik olarak yoksul ailelerden gelmektedir. Her iki okulda akademik başarı düzeyi düşük olduğundan yükseköğretime devam eden öğrenci oranı çok azdır. Öğrenci ailelerinin eğitim düzeyleri düşük, aile içi sorunlar yaygın, geneli çiftçi, yevmiyeci vb. geçici ve güvencesiz işlerde çalışmaktadır. Dört öğrencinin anne-babası ortaokul mezunu, iki öğrencinin anne-babası ilkokul mezunuyken, bir öğrencinin babası, bir başka öğrencinin ise annesi ilkokul mezunudur. İki öğrenci ise ebeveynlerinden birinin okuma yazma bilmediğini ifade etmiştir. Bununla birlikte bir öğrencinin ebeveynlerinden biri lise mezunudur.

\section{Veri Toplama Aracı ve Süreci}

Araştırmada istenmeyen davranışların toplumsal kökenlerine ilişkin katılımcıların kişisel bakış açıları ve deneyimleri anlaşılmaya çalışıldığından (Ritchie ve Lewis, 2013) yarı yapılandırılmış görüşme formları ile yüz yüze görüşmeler yapılmıştır. Araştırmada eğitimciler ve öğrenciler için iki ayrı görüşme formu hazırlanmıştır. Eğitimci görüşme formunda dokuz soru, öğrenci görüşme formunda 25 soru yer almıştır. Görüşme formunun ilk kısmında kişisel bilgilere, sonraki kısmında istenmeyen davranışların kökenleri ve davranışların çözümü konusunda katılımcıların görüşlerini belirlemeye yönelik sorulara yer verilmiştir. Görüşme formundaki soru sayılarının farklılaşmasının nedeni öğrencilerden konuyla ilgili derinlemesine bilgi alabilmektir. Öğrenci görüşme formunda özellikle ailenin sosyo-ekonomik özelliklerinin belirlenmesine öncelik verilmiştir. Öğrencilerin başarı düzeyleri hakkında ise katılımcılara geçmişteki ve görüşme yapıldı̆̆ı dönemdeki başarı durumunu belirlemeye ilişkin sorulara yer verilmiştir. Görüşme formu taslağı nitel araştırma dersi veren bir öğretim üyesinin görüşüne sunulmuştur. Sonrasında eğitim bilimleri alanında dört öğretim üyesinden görüşme formunun amaca uygunluğu, kapsamı ve uygulanabilirliği bakımından uzman görüşü alınmıştır. Görüşmeler, 
katılımcıların izni doğrultusunda ses kayıt cihazı ile kayıt altına alınmış ve ortalama 30 dakika sürmüştür. Katılımcıların cevapları tekrara düşmeye başladığında görüşmelere son verilmiştir.

\section{Verilerin Analizi}

Araştırma verileri katılımcı ifadelerini belirli kavramlar ve temalar çerçevesinde bir araya getirmek, organize etmek ve yorumlamak (Yıldırım ve Şimşek, 2000) amacıyla betimsel analiz tekniği ile çözümlenmiştir. Verilerin analizi için öncelikle ses kayıtları bilgisayar ortamında araştırma soruları doğrultusunda düzenlenmiş, öne çıkan kavram, ifade ve deneyimlere ilişkin çıkarımlarda bulunulmuş, bu çıkarımları desteklemek amacıyla görüşmeci ifadelerinden alıntılara yer verilmiştir. Çalışmada güvenirlik ve geçerlik açısından görüşme kayıtları katılımcılara onaylatılmıştır. Çalışmada katılımcı ifadeleri herhangi bir müdahale olmadan ifade edildiği haliyle verilmiştir. Verilerin analizinde araştırmacı öznelliğini sınırlandırmak üzere katılımcı ifadeleri iki araştırmacı tarafından ayrı ayrı incelenerek ortaklaşılan noktalarda değerlendirmelere yer verilmiştir.

\section{Bulgular}

$\mathrm{Bu}$ bölümde öğretmen ve öğrencilerin görüşlerine ilişkin bulgular yer almaktadır. Katılımc1 görüşlerinde öne çıkan noktalar, kavramlar ve yaşantılar belirlenerek, bu değerlendirmeleri destekleyen katıllmc1 ifadelerine yer verilmiştir.

\section{Eğitimsel yaşantılar ve toplumsal köken özellikleri}

Öğrencilerin eğitim yaşantılarını olumlu veya olumsuz etkileyen birçok etmen vardır. Öğrenci ailelerinin demografik özellikleri, eğitim düzeyi, sosyo-ekonomik özellikleri öğrencinin eğitim yaşantısına ve tercihlerine etki eden başlıca etkenlerdir. Katılımcı ifadelerinden öğrencilerin gelir düzeyi düşük ailelerden geldikleri anlaşılmaktadır. $\mathrm{Bu}$ durum öğrencilerin eğitim yaşantısına olumsuz yansımakta ve ihtiyaçlarını karşılamak için çalışmak zorunda kalmaktadırlar. Öğrenci, yönetici ve rehber öğretmenlerin, öğrencilerin sosyo-ekonomik durumuna ilişkin bazı ifadeleri şöyledir:

“Çiftçiyiz. Köyde oturuyoruz. Annem ve babam çalışıyor. Çiftçilik yapıyorlar.” (Öğrn. 1)

"Memur çocuğu ögrenci sayısı bile bir elin parmakları kadar belki. Kalan esnaf ya da çiftçi... Gelir düzeyi düşük çocuklar neredeyse hepsi! Popüler kültüre ait markalar, son model telefonlar, tabletler burada pek görülen şeyler değil. Yırtık ya da yamalı ayakkabı görüntüsü burada hala tanıdık. Öğretmenlerin yardım ettiği, para topladığı, klyafet, kitap, çanta, forma aldığı öğrenci çok." (M2)

"Öğrencilerimizin çoğu alt sosyo-ekonomik düzeyden geliyor. Çalışması gereken birçok ögrencimiz var. Mesela bu civarda haftasonu limon kesmeye gidip, hafta içi okula gelen ögrencilerimiz var. Ailelerin maddi durumları zayıf. ...servis parası için, öğlen yemeği için, o şekilde çalışması gerekenler de var." (RI)

Öğrencilerin sosyo-ekonomik özellikleri her iki okulda da benzer özellikler göstermektedir. Ailelerin gelir düzeyleri çok düşük hatta bu nedenle çalışmak zorunda kalan öğrencilerin oranı fazladır. Diğer yandan ailelerin eğitim düzeyinin düşük olmasına bağlı olarak, çocuklarının eğitim yaşantısına da olumlu katkısı olmamaktadır. Bir öğrencinin ailesinin eğitim düzeyinin düşüklüğünün, kendi yaşantısına olumsuz etkisi konusunda "Bilinçsizlikten, cahillikten hiç yardımcı olmuyorlar. Onların eğitim düzeyi yüksek olsaydl, ben de daha iyi okula gidebilirdim." (Öğrn.5) ifadesi ailelerin çocuklarının eğitim yaşantılarına yönelik algısını da yansıtmaktadır.

Öğrenciler ailelerinde kararların babaları tarafından verildiğini vurgulamışlardır. Okul kararlarını ise bazı öğrenciler kendileri verirken, bazı öğrenciler babalarının yönlendirmesine göre hareket ettiklerini vurgulamıştır. Bir öğrencinin “...biz diyoruz şurayı okumak istiyoruz, babam da destek oluyor." (Öğrn.6), ifadesindeki gibi aileler çocuklarının eğitim yaşantılarına müdahil olmamaktadırlar. Bir öğrencinin "Aslında önceden SBS vardı her yıl giriyorduk lise için. Ben iki yıl girmedim. 6 ve 7 de girmedim babam yüzünden. 8. sinıfta ben kendi kararımla girdim. Çünkü babam liseye göndermeyecekti, hatta bir yll okula ara verdim. Sonra abimin karariyla buraya yazlldim." (Ö̆grn.1) ifadesi, diğer görüşmelerde de siklıkla karş1laş1lan "baba" vurgusunu göstermektedir. Öğrencilerin eğitim kararlarının büyük ölçüde babalar tarafından belirlendiği anlaşılmaktadır. Bu da 
özellikle babanın eğitim düzeyinin, dünyaya bakışının, meslek ve iş durumunun çocuklarının eğitim yaşantısında birincil etken olduğunu göstermektedir.

Tüm katılımcıların ifadeleri her iki okulda da akademik başarının düşük olduğu yönündedir. Eğitimciler öğrencilerin akademik başarılarının çok düşük olduğunu vurgulamakla beraber, bazı öğretmenler öğrencilerin sosyal açıdan başarılı olduklarını vurgulamıştır. Özellikle almış oldukları mesleki eğitimleri iş hayatında başarı ile kullandıklarını ve sosyal ilişkilerinin de çok iyi olduğunu ifade etmişlerdir.

“...merkezi sınav sistemiyle bakılan başarlya bakıldiğında düşük oluyor. Sosyal başarıya bakarsak, benzer okulların, mesleki ĕgitim vermeyen liselerle kyyaslandığında, sosyal hayatta daha başarıll. ...çünkü en az bir yıl staj yapıyor ve işle ilgileniyor. En kötü ögrenci de bunu ögreniyor ve ne hikmetse bizim burada okulda bir şey olmaz dediğimiz birçok ögrenci, bir şey olur dediğimiz öğrenciden daha çabuk iş buluyor... Bizim bölgemizde piyasaya çıktı̆̆ımız zaman motor ustası da elektrik ustası da mobilya ustası da bu okuldan mezun olmuş..." (Ö2)

"Ilimizdeki en başarısız ögrrenciler bizde. Sinav sisteminde en altta kalanlar diyebilirim. ...İki ylllı üniversiteye giden ögrrenci 10-15 kadar. Üç-dört yıldır, dört yıllık üniversite kazananı hatırlamıyorum. Üç sene önce üç-dört ögrencimiz vardı dört yıllığa giden, bazı yıllar hiç olmuyor bazı yıllar bir-iki." (Ö4)

“...akademik başarısı düşük ögrencilerin toplandığı bir mekândayız şu an... Genel itibariyle ailesinin gözden çıkardı̆̆ı, çevresinin gözden çıkardı̆̆̆ öğrenciler fazla. Yani 'Sen okusan da bir şey olmazsın.' dedikleri öğrenciler ve okumak istemeyen öğrenciler. Bir ilköğretim okuluna gidin okumak istemeyen okuldan kaçan ders çalışmak istemeyen, sevmeyen, akademik başarısı en düşük olan ögrenciler buralara geliyor." (MI)

"Düşük çok düşük....onuncu, on birinci sınıfa gelen bir öğrencinin dört işlem yapamadığını söylesem. Maalesef 1.000 TL'nin \%18 KDV'sini bulamiyor. Hesap makinesi de veriyorsunuz yapamıyor..." (Ö1)

Öğretmenlere benzer olarak öğrenciler de her ne kadar kendi istekleri ile okul tercihlerinde bulunduklarını ifade etseler de akademik başarı düzeylerinin düşük olması nedeniyle meslek lisesini tercih etmek zorunda kalmışlardır. Diğer yandan öğrenciler ailelerinin de kendilerini meslek lisesine özendirdiğini ifade etmişlerdir. Ailelerin çocuklarının kısa yoldan meslek sahibi olmalarını istemeleri gelir düzeylerinin düşük olmasından kaynaklıdır. Meslek lisesi kararı çoğunlukla rasyonel bir tercih gibi görünse de toplumsal köken özellikleriyle derinden bağlantılı bir konudur.

\section{Yaygın istenmeyen davranışlar}

Eğitimcilerin en fazla belirttikleri istenmeyen davranışlar "sigara içme, madde kullanma, devamsızlık, kıyafet kurallarına uymama, argo ifadeler, derste telefon kullanma, şiddet ve okul fişini çalma"dır.

“En çok sigara içme problemimiz var.” (Ö5)

"Tütün kullanımı zaten tüm orta ögretim okullarının ilk siradaki sorunu, bizde hemen arkasindan kllık klyafet, sakal, makyaj sorunlarl geliyor." (M2)

Yöneticilerden biri kıyafet sorunun en önemli disiplin problemi olduğunu ve serbest gelen öğrencinin okulda istenmeyen davranışlar gösterdiğini ifade etmiştir.

"Yoğun olarak klyafete tepki var ögrrencilerimizden,... İște biz takım elbise giydiğimiz zaman davranışlarımız, konuşmamız ona göre oluyor, spor giyindiğimiz zaman ona göre oluyor. Öğrencide de aynı şekilde. Öğrenci dediğiniz formayı giydiği zaman daha öğrenci davranışı sergiliyor öğretmenleriyle ilişkilerinde arkadaşlarıyla iliş̧kilerinde ama yırtık pantolon, tişört giyip geldiği zaman sokaktaki gibi davraniyor." (M3)

İstenmeyen davranışlar ile cinsiyet arasında bağlantı kuran eğitimciler olmuştur. İstenmeyen davranışların erkek öğrencilerden kaynaklandığı yönündeki genel kanının aksine kızların da giderek şiddet eğilimine girdikleri, argo kullandıkları vurgulanmıştır. Bu alg1 aslında bir yönüyle şiddet eğiliminin toplumsal yaygınlaşmasının göstergesidir. İstenmeyen davranışların toplumun genelinde 
yükselmesine karşın, kızlarda bu eğilimin dikkat çekmiş olması da bir başka istenmeyen davranış olan "cinsiyet ayrımcılı̆̆ı"na işaret etmektedir. Bir öğretmen "Kızlar arasında korkunç iletişimsizlik, kavga var. Üst düzeyde geçimsizlik, kıskançlık var." (Ö1) diyerek, durumu toplumsal cinsiyete ilişkin kalıp yargılarla açıklamaya çalışmıştır. Benzer şekilde bir başka öğretmen "Şiddet klz ögrrencilerimizde daha fazla." (Ö2) diyerek, diğer öğretmenin görüşlerini destekler nitelikte ifadeler kullanmıştır. Öğretmenlerini kız öğrenciler konusundaki görüş benzerliğini gösteren bir diğer ifade şöyledir:

"Kız ögrencilerimizde ciddi davranış bozukluğu olmaya başladı. Daha kaba, daha rahat küfür eden, daha rahat kavga eden ve mesela sokakta yürürken dolmuşa gidene kadar daha çok rahat sigara içebilen kız ögrencilerin sayısı arttı." (Ö3)

Her üç öğretmenin istenmeyen davranışların erkek öğrencilere özgü olduğu yönünde toplumsal cinsiyet kalıp yargılarına sahip olduğu gözlenmiştir. Öğrencilere göre okul içinde en yaygın istenmeyen davranışları şunlardır: okul kıyafeti giymeme, sigara ve madde kullanma, küfürlü konuşma, devamsızlık, hırsızlık, telefon ile okula gelme ve okuldan kaçma, motor kullanma, okul fişi çalma. Öğrencilerden bazıları sigara dışında başka maddelerin de okul içi ve dışında kullandığından söz etmiştir.

"Uyuşturucu. Tabi jandarma bölgesi olduğu için sürekli jandarma geliyor. Okuldan alıyorlar, jandarma götürüyor. Jandarma geri gönderiyor. Size pencereden gösterebilirim, şu anda okulda kimse yok ama, karne günü göstereyim size tek tek. 100'ü aşkın ögrenci gösterebilirim..." (Ö̈̆rn.6)

“... Okulda madde bağımlıları var. Ve okulda esrar içiyorlar. Bunu okula getiriyorlar bahçede içiyorlar. Bir de hap getiriyorlar...” (Öğrn.2)

Bir öğrenci okula amaçsız gelen öğrencilerin çok olduğuna değinmekle birlikte diğer öğrencilerin dile getirmediği bir soruna da dikkat çekmiş ve öğrencilerin motor kullanımından dolayı ölümlü trafik kazalarının sık yaşandığını belirtmiştir.

“... Okula amaçsız gelen öğrenci sayısı çok fazla. Bizim okulda aşırı derecede motorlar meşhurdur. Trafik kazalarında ölenlerin saylsı çok yüksek. Ben de trafik kazası geçirdim..." (Ö̈̆rn.8)

Görüşmelerde fazla vurgulanan istenmeyen davranışlardan biri devamsızlık ve okul terkidir. Eğitimcilerin tümü devamsızlık ve okul terkinin özellikle 9. sınıfta yüksek olduğunu vurgulamıştır.

"Devamsızlık çok olan ve devamsızlıktan kalan ögrenciler genellikle sılkıntılı ailelerden gelen gençler, problemli gençler çoğu da madde kullanıcısı. Okul bırakma da oluyor. 9. sınıflarda yoğun oluyor." (R3)

“9. sınıflarda çok fazla. Şu an 9. sınıflarda listeye baktığımız zaman 30 ögrenci görünüyor, ama sinıf mevcutları 20 civarında şu an. Yani üçte biri kayıp." (R1)

Bir öğretmen de 9. sınıfta devamsızlık ve okul terkinin yoğun yaşanmasının nedenini bu aşamada eğitim hayatına devam etmek isteyen öğrenciyle istemeyen öğrencinin açığa çıkmasına bağlamıştır.

“....Bir ilköğretim okuluna gidin okumak istemeyen okuldan kaçan ders çalışmak istemeyen sevmeyen akademik başarısı en düşük olan öğrenciler buralara geliyor. Bu ögrencilerden de bir kısmı özellikle de 9. sınıfta en fazla kayıp oluyor. Okulu bırakıyorlar. Kimisi hiç gelmiyor hiç başlamıyor. Açık liseye giden ögrencilerimiz var. En çok 9. sinıfta. 9. sinıfi geçen öğrenciler artık 10. sınıfa geçtikten sonra bölümlere geçtikten sonra okulla bağlantılarını kolay kolay koparamıyorlar. Daha doğrusu okuyacak ögrenci 10. sınıfa devam etmiş oluyor..." (M2) 


\section{İstenmeyen davranışların kaynakları}

Araştırmada eğitimciler istenmeyen davranış kaynakları konusunda en fazla aile ve toplumsal çevreye işaret etmişlerdir. Tüm katılımcıların birleştiği ortak noktalar; ailelerin parçalanmış olması, aile içi ilişkilerin zayıf olması, ekonomik ve eğitim seviyesinin düşük olması.

"Disipline giden kiz çocuklarım vardl, ilgisiz aile gördüm mesela. Köyde çocuk, anne burada ev tutmuş, yalnız kalmış, bir kız çocuğu o yaşta ne kadar otokontrolünü koruyabilecek. Ondan kaynaklanan sorunlar olabiliyor." (M2)

Eğitimci ifadelerinden, ailelerin okula ve öğrenciye yeterli ilgi ve alakayı göstermedikleri anlaşılmaktadır. Ailelerin ilgisizliği katılımcılarca özellikle vurgulanmıştır. Ailelerin önceliklerinin çocuklarının temel gereksinimlerini karşılamak olduğu söylenebilir. Temel gereksinimlere odaklanma büyük ölçüde yoksul toplumsal köken göstergelerinden biridir. Öncelikli amaç fizyolojik gereksinimleri karşılamak, yaşamı sürdürebilmektir.

“...Açık açık da söylüyorlar 'hocam daha ne yapabilirim? Okula gönderiyorum, harçlı̆̆ını veriyorum ayakkabisinı alıyorum, daha ne yapayım?' diyor.” (R2)

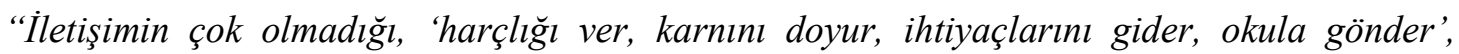
felsefesinin hâkim olduğu bir aile ilişkisi ..." (M2)

Toplantılara katılımın az olduğunu ifade eden bir eğitimci "Ben sınıf öğretmenliği yaptı̆̆ım zamanda hiç getirtemedim... Hiç gelmiyorlar, hiç merak etmiyorlar çocuklarını." (Ö1) ifadesi velilerin gündemlerinin çocuklarının eğitim yaşantıları olmadığını gözler önüne sermektedir.

Ailelerin öncelikleri temel gereksinimleri karşılamak olduğunda diğer gereksinimler ihmal edilmektedir. Aileler zorunlu kalmadıkça okula gelmemekte özellikle okulun son günlerinde "devamsızlık sorma, öğrencinin raporunu getirme, bölüm seçimi, öğrenci başarı durumunu öğrenme ve okulda yaşanan sorun" durumlarında gelmektedirler. Bir eğitimci öğrenciyle ilgili çok ciddi problemlerin olmasına karşın, ailelerin duyarsız kalabildiklerini belirtmiştir.

“...benim mesela istismar dosyalarım vardl, mahkeme kararlyla okuttuğumuz ögrencilerimiz vardl. Telefonla veli çağırlyoruz, veli gelmiyor ve ben bunlarla ilgili mahkemeye rapor yazıyorum, plan yapıyorum mahkemeye gönderiyorum. O plana uygun olarak aylik faaliyetler yazıyorum. Veli ayağı eksik kalıyor. Hâkim olmaz diyor veliyi getirteceksin diyor." (R3)

Öğrenciler de eğitimcilerle benzer şekilde, ailelerin çok sık okula gelmediklerini belirtmişlerdir. Ailelerin zaruri olmadıkça okula uğramadıklarına yönelik genel bir görüşün hâkim olduğu anlaşılmaktadır. Bununla birlikte öğrencilerin, ailelerinin okulla ilişkilerinin yoğun olmasını istemedikleri anlaşılmaktadır. Bir öğrencinin "Çok sık gelmemeleri iyi. Beni slkmıyorlar." (Öğrn.4) ifadesi, sıklıkla paylaşılan bir durumdur. Öğrenciler ailelerinin okula az geliyor olmasından şikâyetçi olmadıkları gibi bu durumdan memnun olduklarını da ifade etmişlerdir. Özellikle olumsuz yaşantıları olan öğrenciler durumlarının, aileleri tarafından öğrenilmemesi hatta ailelerinin üzülmemesi için okula s1k gelmelerini istemediklerini belirtmişlerdir.

“...Çok üzdüm ailemi, yapma dediklerini yaptım, ders çalış dedi çalışmadım, yapma dedi yaptım. Biraz karşı geldim. Öğrendiklerinde üzülürler, ben niye böyle çocuk yetiştirdim diye...” (Ö̈̆rn.5)

"Notlarım iyi olsaydı her gün gelmelerini isterdim. Ama şuan notlarım onların istediği gibi olmadı̆̆ l için gelmelerini istemiyorum." (Öğrn.7)

Bazı eğitimciler öğrencilerin özellikle hedefsiz oldukları için istenmeyen davranış gösterdiklerini ifade etmiştir. $\mathrm{Bu}$, daha önce ifade edildiği gibi ailelerin çocuklarının temel gereksinimlerini karşılamaya odaklanmalarından kaynaklı bir durum olarak değerlendirilebilir.

"Bizim burada okulu bitiren öğrencilerimiz boşta geziyor, ĕger onlara iş imkânı verilse çocuklar bir hedef kazanmış olur. O şey kendisindeki o önyargıyı, benden hiç bişey olmaz, bir şeyi başaramam o şeyi kırar, bir hedef vermiş oluruz ögrenciye. İster istemez kendini frenleyecektir, bir amact olacaktır." (R1) 
Bir öğretmen istenmeyen davranışların bir kısmının çocukların toplumda birey olarak kabul ve sayg1 görmemelerinden kaynaklı olduğunu vurgulamıştır. Öğretmenin “...aile içinde önemsenmemiş, kendini burada göstermek için bir şekilde öne çıkmak için kavgacı oluyor.” (Ö1) ifadesi öğrencilerin saygı görmemelerinden kaynaklı eksikliği, istenmeyen davranışlar göstererek kendilerine toplumsal bir konum elde etme çabasına girebildiklerini göstermektedir.

Bir rehber öğretmenin "Kavga eden çok sıkıntı yaşayan çocuklara bakıyorum anne ile ilgili problem var. Anne konuşmuyor, anne ayrılmış başkasıyla evli, orda problem yaşıyor." (R2) ifadesi öğrencinin istenmeyen davranışını anne kaynaklı olarak görmesi, istenmeyen davranışları toplumsal cinsiyet kabulleri çerçevesinde değerlendirdiğini göstermektedir. İstenmeyen davranışın gerçek kaynaklarına ilişkin çözümleme bu durumda yetersiz kalmaktadır. Bununla birlikte özellikle akran etkisinin ön plana çıktığı dile getirilmiştir.

"Disiplin sorunu tamamıyla neye bağlı derseniz, arkadaş derim ben, çünkü onların dünyasında 15-17 yaş grubu, anne-baba, ögretmenden önemli, arkadaş. Arkadaş dediği için ölüme bile gidilir yani. Niye gittin kavga ettin kızım diyorum. Arkadaşım için diyor, ben arkadaşım için yaparım diyor." (Öl)

Diğer eğitimcilerden farklı olarak istenmeyen davranışları öfkeyi kontrol edememeye bağlayan bir eğitimci ise öğrencilerin içinde bulundukları ruhsal durumun onları olumsuz etkilediğini ifade etmiştir.

“....sorunun kaynă̆ı genellikle öfke kontrolü sıkıntısı var gençlerde. İstediğini söyleyemeyince yapamayınca ne oluyor, bu ister istemez psişik birikim yaratıyor, gerilim oluşturuyor. Bu gerilim daha sonra da öfke patlamalarina neden oluyor. Ülke olarak halk olarak öfke kontrolünde sıkıntı yaşlyoruz. Bu çocuklarda daha fazla..." (R3)

Bir rehber öğretmenin disiplin sorunlarını öğrencilerin zihinsel kapasiteleriyle ilişkilendirmesi araştırmadaki çarpıcı noktalardan biridir. Öğrenci davranışlarını anlaması beklenen eğitimcinin indirgemeci bir bakış açısıyla meslek lisesine gelen çocukların zihinsel kapasitelerinin yetersiz olduğuna kanaat getirmiş olması, bu nedenle aslında meslek liselerinde istenmeyen davranışların beklenenin altında olduğunu ima etmesi dikkate değer bir noktadır.

"Ben İstanbul'da meslek lisesinde, Edirne'de de çalıştım. Bundan daha yoğun problemli. Aşağı yukarl veli profili, ögrenci profili benzer, problem daha fazla. ... Şöyle vurgulayayım: ...genelde kaynaştırma ögrencileri bize geliyor. İster istemez onun yanında akademik başarısı, zekâ seviyesi, biraz ă̆ır bir şey olacak ama, biraz daha düşük öğrenciler gelmeye başladı fazlastyla...." (R1)

Aynı eğitimci, “...devletin bizden beklentisi şey gibi geliyor: şimdi bu çocuklar sabah nereye gittiği belli olsun, akşam belli olsun, dışarıda boş gezmesin sokakta, burada olsun." (RI) ifadesiyle özelikle öğrencilerin okullar aracılığıyla denetim altında tutulduğunu vurgulamıştır. Bir başka ifadeyle öğretmen meslek liselerini başka seçenekleri olmayan yoksun ailelerin zihinsel yönden zayıf çocuklarının zamanlarını geçirdikleri bir yer olarak görmektedir.

Öğrenciler genel olarak istenmeyen davranışların, aile yapısı ve arkadaş çevresinden kaynaklandığı noktasında birleşmiştir. Bir öğrenci ise arkadaş çevresiyle birlikte öğrencilerin uyuşturucu madde kullanımından dolayı da okul içinde disiplinsiz davranış gösterdiğini belirtmiştir.

"Arkadaş çevresi ve uyuşturucu maddeden dolayı. Bu çok etkiliyor. Çocuk o anda kendinde olmuyor, çocuk hap atmış, gelmiş okula. Bu olay iki hafta önce oluyor, 'ben hap attım' bağırıyor etrafa 'bana bulaşmayın lan!' diyor. Okulda huzursuzluk yaratıyor.” (Öğrn.10)

Bazı öğrenciler ekonomik sıkıntıların dolaylı olarak istenmeyen davranışlara yol açtığını ifade etmiştir. Bir öğrenci "Hepsinin başı sigara. Sigara içmedikleri için sinirli oluyorlar ... Sigara almak için hırsızlık yapıyorlar." (Öğrn.5) diyerek, istenmeyen davranışların birbiriyle bağlantısına dikkat çekmiştir. Bir başka öğrenci de yine "Mesela cebinde parası olmadı mı, arkadaşı telefonu bırakıp gitmiş, onu çallyorlar, satıyorlar." (Öğrn.3) diyerek ekonomik yetersizliklerin istenmeyen davranışların önemli bir kaynağı olduğunu vurgulamıştır. Bir öğrenci ise istenmeyen davranışları yaşlarına bağlamış ve yasak olanın cazip geldiğini söylemiştir. 
"Normal. Çünkü yaşımız gereği, mesela siz yapmak istemezsiniz ama bize çok çılgın geliyor o hareketler. Çünkü yaşımız gereği cidden bizim hoşumuza gidiyor, değişik geliyor ilk kez yapıyorsun falan heyecan oluyor ama tabi suçları da oluyor. Mesela burada sigara içmek... Her zaman bir şeyi kaçak yapınca daha güzel gözüküyor. Mesela teneffüste gidiyorsun bir arkadaş lavaboda bekliyor bir arkadaş orda içicem çabasina giriyo o onu çekiyor, o onu içiyor ondan sonra çıkıyor teneffüs ne ara bitiyor anlamıyorsun, bir şeyler oluyor yani. ...Herkes için böyledir sadece benim için değil." (Öğrn. 9)

Diğer taraftan bir eğitimci de özellikle okula gelmek istemeyen öğrencinin okulda problemler çıkartarak kendini okuldan bilinçli bir şekilde attırma yoluna gittiğini belirtmiştir.

"Okulda tuvalet kapılarını kırma olayı yaşandı ve kimin yaptığını tahmin ediyorduk. Velisine ben durumun sıkntılı olduğunu anlattım, açık liseye almasının daha doğru olacağını anlattım. Çocuk da söylüyor zaten 'Beni açı liseye alın, okula gelmek istemiyorum.' diyor. Babasına diyor ki 'Beni okuldan al açık liseye kaydımı yaptır.' Gitmek için, kendini attırmak için disiplin olaylarına falan giriyor disiplin suçu işliyor ki beni kovsunlar.” (M3)

Devamsızlık ve okul terkinin nedenlerine ilişkin eğitimcilerin çoğunluğunun üzerinde durduğu konu özellikle ailenin ekonomik yapısıdır. Ailenin ekonomik durumuna vurgu yapan eğitimciler öğrencilerin çalışmak zorunda oldukları için okula gelemediklerini dile getirmişlerdir.

“... Çocuğun ihtiyacı var işe gidiyor. Sorduğumuz zaman ögrenciyle birebir ilgilendiğimizde oğlum niye gelmedin diye sorduğumuzda 'Bugün yevmiyeye gittim.' \%70'i bu cevabı allyor." (Ö2)

“....veli geliyor ağlamakl oluyor üzülüyorum. Onu bir şekilde örtbas etmeye falan çalışıyorum, 'Niye devamsızlık yaptın çocuğum?' diye ...velinin yanında az bir azarlar konuşma biçimine büründüğ̈̈m zaman, veli ağlamakl bir şekilde 'Onu ben gönderemedim, yol parası bulamadım o gün.' diyor. Bunlara da tanık oluyorum. Ekonomik nedenlerden dolayı veya diyor ki ben göndermedim hocam işe gönderdim iki gün portakal kesmeye gönderdim falan gibi şeylere de tanık olduk..." (M3)

"Hafta sonu tarlada, bağda, bahçede çalıştırlldığı için, hafta sonu çocuk kendi özgür bir şekilde sağda solda gezemiyor. Hafta içi okula geliyor ancak okulu asarak o tür şeyler yapabiliyor. Bazı ögrrenciler var köylerden gelen ögrrenciler var. Çocuk evden çıkıyor servisle okula geleceğim diye evden çıkıyor, çarşıda iniyor ve çarşıda iki üç kişi beraber olup geziyorlar akşama kadar..." (M2)

“...Ekonomik yapıları düşük aileler ikinci şansı vermiyor. Hani sınıfta kalan, ...velilerimizden duyduğumuz şey de bu. 'Bu çocuğu ne olur geçirin, kalırsa bir daha göndermeyeceğim.' Ya da çocuk da bize o şekilde geliyor: 'Lütfen hocam ne olur bu dersten ödev getireyim, beni bir daha sınav yapın ama geçmem lazım, kalırsam ailem bir daha okula göndermeyecek.' diyor. Yani ikinci bir şansı aile vermek istemiyor çocuğuna. Haklı da görüyoruz aslında bir yerde. Ekonomik olarak karşılayamayacağını düşünüyor ..." (Ö3)

"Büyük çoğunluğunda durum doğru orantıll. Okulu sevmeyen ögrrenci devam etmiyor, devam etmedikçe okul kültüründen kopuyor, koptukça sahiplik ve aidiyet hissi yerini, disiplin sorunlarına biraklyor." (M1)

Diğer yandan bir eğitimci ise okul terki konusunda diğerlerinden farklı olarak özellikle kız ögrencilerin evlenmesinden dolayı okul terki yaşandığını, bunun da nedeninin aile yapısından kaynaklandığını vurgulamıştır.

"Kız ögrrenciler de ne yazık ki erken evlilik gibi bir problemimiz var... Çocuk bir yere ait olmak istiyor doğal olarak. Değerli olmak istiyor, birinin ona değer vermesini istiyor. Anne, baba, birinci dereceden yakınlar değilse, bunu kendisine verebilecek ilk kişi kimse..." (Ö3)

Devamsızlık sorunu katılımcıların hepsi tarafından vurgulanmıştır. Bununla birlikte bu sorunun başka bir disiplin sorununa yol açtığı da bazı öğrenciler tarafindan ifade edilmiştir. Yoklama fişini çalma bunlardan biri ve hatta bu sorunun da yine öğrenciler arasında kavgaya yol açabildiği belirtilmiştir. 
“....Fiş çalma olayı çok, akşama kadar okula gelmiyorlar. Akşam okula geldiğinde fişi alıp gidiyor. Bu da sorun oluyor. Fişten sorumlu öğrenci kendi başının yanacağını bildiği için yapan kişiyi söylüyor. Kendi başı belaya girmemesi için söylüyor. Tabi kaçan kişi kavgaya meyilli, sorunlu olduğu için sorun çıkıyor ..." (Öğrn.10)

Aynı öğrenci okulda hırsızlık olaylarının da yaşandığını söylemiştir.

“... Bu okulda hırsızlık da var. Biz soyunma odasındaydık iki tane arkadaşım var sınıftan arkadaşlar cüzdanlarını bırakmışlar parayı almışlar. Telefon da çok çalınıyor bizim okulda. Soyunma odasından telefonu çok çalınan oldu. "(Öğrn.10)

\section{İstenmeyen davranışların çözümü}

Eğitimcilerin ve öğrenciler büyük ölçüde öğrencilerin istenmeyen davranışlarını içinde bulundukları koşullar nedeniyle normal karşılamaktadırlar. Bir öğretmen "Bu şartlarda normal. Yani böyle bir ortamdan gelmiş bir ögrencinin disiplinli olması beklenemez." (Ö2) diyerek istenmeyen davranışların hayat şartlarının bir sonucu olduğunu vurgulamıştır. Bir başka öğretmen de istenmeyen davranışların sonuç olduğuna, bu sonucu ortaya çıkaran nedenlere odaklanılması gerektiğini vurgulamıştır.

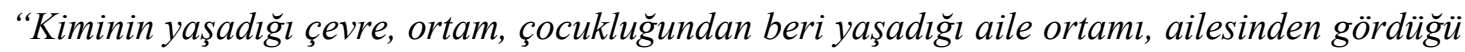
davranışlar, onun öyle bir kişilik geliştirmesine sebep oluyor ki, agresif hirçın, saldırgan, yani genellikle de kaybedeceği bir şey olmayan çocuklar oluyor. Yani bir saygınlık yok, ailede saygınlık yok, okulda saygınlı yok ya da elinde bir şey yok çocuğun kaybedeceği bir şeyi olmayınca daha gözü kara, daha korkusuz, daha her şeyi yapabilen insanlar haline gelirler ya işte, bu çocuğu tabi ki suçlamıyoruz. Bunu haklı gördüğümüz anlamıma gelmez. Sadece anlamaya çalışmamız ve nasıl yardımcı olabilir noktasında yardım etmemiz gerekiyor." (Ö4)

Cezanın davranış değişikliği oluşturmadığını ifade eden başka bir eğitimci de öğrenciye ceza vermek yerine onların iyi oldukları noktaları keşfetmeye çalışılması gerektiğini vurgulamıştır.

"Biz çocukları cezalandırmaktan ziyade onların iyi olduğu noktaları ön plana çıkarıp onları takdir ederek, onlara duymak isteyecekleri şeyleri söyleyerek kazanmaya çalışlyoruz. Yani korkutarak sindirerek değil, çünkü bu zaten bize kat be kat agresif, kat be kat davranış bozukluğu olan çocuk olarak geri dönüyor. Burada çocuğun iyi olan tarafinı, zaten eğitimde de amaç budur..." (Ö3)

Daha iyi bir eğitim-öğretim ortamı oluşturmak ve istenmeyen davranışların önüne geçebilmek amacıyla hem eğitimciler hem de öğrenciler sosyal etkinliklerin artırılması öğrencilere yönelik yapılabilecek rehberlik hizmetleri ve aile eğitimi ile istenmeyen davranışların çözülebileceği konusunda ortak bir yargıya vardıkları görülmüştür. Bir eğitimci bu konuda okul içinde yapmış oldukları sosyal faaliyetler ile istenmeyen davranış sorunlarının üstesinden geldiklerini, dolayısıyla bu konuda başarılı olduklarının altını çizmiştir.

“....bizim burada disiplin problemini çözmemizdeki en önemli şey sosyal etkinliklerdir. Okulu seviyor, okulu sevdiği zaman sınıfi kirletmiyor, dersi dinliyor, kırmıyor sırayl, seviyor çünkü orayl. Burayı kötü gördügü zaman tavana basıyor. Tavanda kaç kere ayak izleri vardı eskiden, sevmiyor zarar vermek için elinden geleni yapıyordu." (R2)

Bir başka eğitimci de bu görüşü destekler nitelikte yanttlar vermiştir. Öğrencilerle iletişim kurulması onların kendilerini değerli hissetmelerini sağladığını ve bu iletişimin de öğrenciyi olumsuz davranışlardan alıkoyduğunu belirtmiştir.

“....buradaki öğrenci sevmeye, sevilmeye muhtaç. Burada öğrenciye biraz ilgi gösterdiğinizde, biraz samimiyetle sevginizi gösterdiğinizde ögrenci siz ne derseniz yapmaya hazır halde oluyor... Değer verildiğini gördüğ̈̈nde o zaten diğer öğrencilerden kendisinin farklı olduğunu hissediyor o anda. Ögretmen beni seviyor, diğer ögrencilere göre farklılık kazandı̆̆ını düşünüyor, ...o anlamda etkili olabiliyor. " (M1)

Araştırmaya katılan eğitimci ve öğrenci ifadelerine göre okulda yapılacak sosyal etkinliklerin, programa yönelik yapılacak değişiklerin ve aile-okul ilişkilerinin geliştirilmesi okulda istenmeyen 
davranışları azaltacaktır. Bununla birlikte eğitimciler okula yönelik aidiyet oluşturmanın, devamsızlık hakkında bilgilendirme yapılmasının, okula ulaşımın devlet tarafindan karşılanmasının ve ailenin eğitiminin bu konuda etkili olabileceğini dile getirmişlerdir. Bir öğretmen ise bu konuda veliye yönelik de bir yaptırımın olması gerektiğini belirtmiştir. Ayrıca motor kullanan öğrencilerin çok olması kazaları da beraberinde getirdiğini vurgulamıştır. Araştırmada dikkati çeken önemli noktalardan biri katılımcıların sosyal sınıf temelli yaklaşmalarının sınırlığıdır. Katılımcılar ailelerin ve öğrencilerin dezavantajlı şartlardan geldiklerini ve istenmeyen davranışların bu dezavantajlarından kaynaklandığını dile getirmelerine karşın dezavantajı konumun nedenleri ve eşitlikçi bir toplumsal düzen çözümü konusunda görüş dile getirmemişlerdir.

\section{Tartışma, Sonuç ve Öneriler}

Araştırmanın gerçekleştirildiği mesleki-teknik lise öğrencileri dezavantajlı ailelerden gelmektedir. Ailelerin eğitim düzeyi düşük, ekonomik kaynakları yetersiz, yaşamlarında eğitime dayalı kazanımları çok az olmakla birlikte çocuklarının eğitim yaşamlarına destekleri sınırlı kalmaktadır. Dezavantajlı sosyo-ekonomik yaşantı öğrencilerin eğitime yönelik planlarını da şekillendirmektedir. Birçok öğrencinin meslek lisesine gelme nedeni kısa zamanda bir beceri kazanarak çalışma yaşamına başlamak ve ekonomik kazanç elde etmektir. Dezavantajlı hayat şartlarının öğrencilerin ve ailelerinin eğitim tercihlerini etkilediği çok sayıda araştırma ile ortaya konmuştur (Buyruk, 2009; Bülbül, 2012; Tunç, 2011; Vuranok, Özcan ve Çelebi, 2017). Bu araştırmalarda özellikle alt sosyo-ekonomik kökenli öğrencilerin mesleki programlara yöneldikleri, hayat şartlarının zorluğu nedeniyle devamsızlığın ve okul terkinin daha fazla gözlendiği sonucuna ulaşılmıştır. Ayrıca Buyruk'un (2009) eğitimde yaşanan toplumsal eşitsizlikleri değerlendirdiği araştırması da kişilerin eğitim hakkından yararlanma biçimlerinin sahip oldukları toplumsal, ekonomik ve kültürel özelliklere göre şekillendiğini göstermektedir. Orta-üst gelir grubundan eğitim seviyeleri yüksek ve hayat koşulları iyi olan ailelerin çocukları büyük oranda yüksek puanla öğrenci alan yükseköğretim programlarına devam etmektedirler.

İstenmeyen davranışların nedenleri konusunda katılımcıların ortak noktası ailevi ve toplumsal çevreden kaynaklı durumlardır. Öğrencilerin okul tercihlerinde baba figürü baskındır. Babalar ailenin ekonomik kaynak sağlayıcısı olarak çocuklarının da en az maliyetle, en kısa yoldan gelir elde edebilecekleri mesleki-teknik liselere yönelmelerini desteklemektedir. Diğer yandan öğrencilerin büyük bölümü lise öncesinde akademik başarılarının düşük olmasına bağlı olarak liseye geçiş aşamasında zorunlu olarak meslek lisesini tercih etmişlerdir. Bir başka ifadeyle ortaöğretime geçiş puanları ancak meslek lisesine girebilmeye yettiği için tercih etmişlerdir. İlk bakışta rasyonel bir tercih gibi görünen meslek lisesi, öğrencilerin temel eğitimdeki akademik başarılarının düşüklüğünün sonucudur. $\mathrm{Bu}$ yargıyı eğitimcilerin ifadeleri de desteklemiştir. İlköğretimde akademik başarısı düşük ve ortaöğretime geçiş sınavında en düşük puanı alan öğrencilerin kendi okullarına geldiğini belirtmişlerdir. Yine eğitimciler başka okullara gitme seçenekleri sınırlı olan öğrencilerin çoğunlukta olmasının yükseköğretime gitme oranlarını da çok düşürdüğünü dile getirmişlerdir. Eğitimciler kendi okullarında bazı yıllarda dört yıllık bir program puanı alan öğrenci olmadığını dile getirmişlerdir. Bu da yoksul aile kökeninden kaynaklı bir durumdur. Yoksul aile çocuklarının üst basamaklardaki oranı toplum nüfusu içindeki oranından düşüktür. Karatape (2016) özellikle varsıl çevredeki öğrencilerin eğitim koşullarının iyileştirilmesinin yoksul çevredeki dezavantajlı koşullardaki öğrencilere oranla, "nitelikli” okullara gitme olasılığını çok arttırdığını belirtmektedir. Bu aslında Bourdieu'nün (2015) de vurguladığı gibi toplumsal katmanlaşmanın eğitimsel başarı ve tercihler üzerinden doğal bir tercihmiş gibi gösterilmesidir. Vurucu'nun (2010) araştırmasında benzer şekilde meslek lisesi öğrencilerinin dörtte üçü kadarının meslek lisesinin kendi tercihleri olduğu yönündeki belirlemesi toplumsal kökenin eğitimsel tercihlerde etkisinin doğal karşılandığını göstermektedir. Erkul ve Dalgılıç (2014) ile Tunç, Yıldız ve Doğan (2015) da mesleki-teknik liselere gelen öğrencilerin çoğunluğunun akademik başarılarının düşük, sosyo-kültürel ve ekonomik düzeyleri zayıf ailelerden geldiklerini belirtmişlerdir.

Araştırmada dikkati çeken bir diğer nokta eğitimcilerin okullarındaki öğrencilerin mesleki yatkınlıklarının, çevrelerindeki küçük ölçekli işletmelerde tercih edilmesini sağladığı yönündeki ifadeleridir. Bourdieu (2015a) "habitus" kavramı ile toplumsal köken özelliklerinin bireylerde algılama, düşünme ve davranışlarda yatkınlık ve eğilimi artırdığını belirtir. Öğrencilerin ailelerinin de büyük ölçüde beden işi ile uğraşmaları çocuklarında da bu eğilimin olduğunu göstermektedir. Yine Bourdieu'nün (2015b) babanın eğitim, meslek ve kültürel sermayesinin, çocuklarının gelecek 
yönelimlerini en fazla etkileyen değişken olduğu yönündeki araştırma sonucu bu araştırmada da öğrencilerin, özellikle babalarının yönlendirmesiyle okul tercihlerini yaptıklarını belirtmeleriyle tutarlıdir.

Araştırmada sosyo-kültürel özellikler ile eğitimsel davranışların ilişkisini gösteren bir diğer nokta veli-öğrenci-okul ilişkileridir. Görüşmelerde velilerin problem yaşandığında, devamsızlık yapıldığında, çocuklarının başarısızlık durumunda sınıf geçmelerini veya not yükseltmeyi talep etmek amacıyla okula geldikleri vurgulanmıştır. Sayılan bu durumlar sonuç niteliğindedir. Yani veliler çocuklarının eğitim süreciyle ilgilenmemekte, belli başlı zorunluluklar durumunda okulla iletişime geçmektedirler. Velilerin okula ilgi göstermemeleri de sosyo-kültürel değişkenlerle ilişkilendirilebilir. Aileler çocuklarının temel gereksinimlerini karşılamayı öncelikli amaç olarak görmekte eğitim gibi ikincil amaçları ise ihmal etmektedirler. Bu ihmal öğrencilerin örneğin okula gitmek yerine arkadaşlarıyla gün içinde dolaşma, zararlı alışkanlıklar veya bağımlılık yapıcı maddeler kullanma gibi olumsuz davranışlarının gözden kaçırılmasına yol açabilmektedir. Öyle ki bazı aileler çocukları sınıf tekrarı yapması durumunda okuldan alacaklarını dile getirmektedirler. Bu düşünce eğitimin, ailenin yaşamsal gereksinimlerine bir katkısının olmamasının yanında, fazladan maliyete yol açan bir durum olarak algılandığını göstermektedir. Biber (2003) araştırmasında alt sosyo-ekonomik düzey ailelerin okul ziyaretlerinin düzensiz ve toplantılara katılma nedenlerinin ise sadece not öğrenme amaçlı olduğu sonucuna ulaşmıştır. Diğer taraftan üst sosyo-ekonomik düzey aileler okulla her türlü iletişim yöntemlerini kullanırken toplantılara öğrencilerin arkadaş ilişkilerini, sosyal faaliyetlere katılımını öğrenmek için katılmaktadırlar. İşgingöz ve Bülbül'ün (2012) araştırmasında yöneticiler okul-veli diyaloğunu yetersiz bulmuşlar, diyaloğun okulda yaşanan disiplin sorunlarının ve davranış problemlerinin, şiddet ve çeteleşmenin azaltılmasına, öğrenci başarısının arttırılmasına katkı sağlayacağını ifade etmişlerdir.

Araştırmada en yaygın istenmeyen davranışlar, sigara içme, madde kullanma, devamsızlık, argo kullanımı, şiddet içeren davranışlardır. Her iki okulda da madde bağımlılığının yaygın olduğu dile getirilmiştir. Katılımcılar ailelerin kendi sorunlarıyla ilgilenirken çocuklarının yaşantılarını ve arkadaş ilişkilerini ihmal ettiklerini vurgulamışlardır. Özellikle aile içi iletişim sorunu ve parçalanmış aile durumları sıklıkla vurgulanmıştır. Gürol (2008) akran etkisinin özellikle madde kullanımında etkili olduğunu vurgulamakta, özellikle başarı düzeyi düşük ve ailelerinde uygun ortamı bulamayan öğrencilerin bu açığı kendisi gibi benzer sorunları yaşayan akran gruplarında bulduğunun altını çizmektedir. Ayrıca Gürol madde kullanımın kabul görmede bir etken olduğunu da ifade etmektedir. Birçok çalışmada benzer sonuçlara ulaşılmıştır. Benzer olarak Yıldırım (2010) demokratik anne-baba tutumu ve ekonomik durum yükseldikçe sınıf içi istenmeyen davranış sorunlarının azaldığı, otoriter anne-baba tutumu arttıkça davranış sorunlarının çoğaldığını belirtmektedir. Kuş ve Karatekin (2009) özellikle anne ve babanın eğitim düzeyi düştükçe istenmeyen davranışların oranının arttığını ifade etmişlerdir. Toytok ve Yıldırım (2018) da öğrenci yoğunluğunun fazla ve başarı düzeyinin görece düşük olduğu meslek liselerinde disiplin sorunlarının daha fazla yaşandığını ifade etmişlerdir.

Araştırmada birçok istenmeyen davranışın zincirleme oluştuğu belirlenmiştir. Örneğin devamsızlık yapan öğrencilerin okul fişlerini almaya çalışırken fişlerden sorumlu arkadaşlarına şiddet uyguladıkları yine sigara ve madde kullanan öğrencilerin parasız kaldıklarında arkadaşlarının telefonlarını sattıkları veya zorla para aldıkları belirlenmiştir. Kıyafet kurallarına uymama, argo kullanımı, telefonun derste kullanılması katılımcıların dile getirdiği diğer sorunlardandır. Katılımcıların üzerinde durduğu diğer bir konu ise bazı istenmeyen davranışların kız öğrencilerde daha fazla yaşandığıdır. $\mathrm{Bu}$ değerlendirmeler, istenmeyen davranışlara, toplumsal cinsiyet kalıp yargılarıyla yaklaşıldığını göstermektedir. İstenmeyen davranışlara ilişkin sayısal veriler cinsiyetlere göre değişse de bu biyolojik cinsiyetle ilgili olmak yerine toplumsal davranış kalıplarıyla bağlantılıdır. Kız öğrencilerde istenmeyen davranışların çoğalması toplumdaki istenmeyen davranışların yaygınlaşmasıyla ilgilidir. Bu da ekonomik, sosyal, kültürel boyutları olan derinlikli ve çok boyutlu bir durumdur. Konuyu ahlaki yetiştirmeye sıkıştırmak sorunun temel kaynaklarının anlaşılmasını önleyecektir.

İstenmeyen davranışların önemli bir kısmı öğretmenlere karşı yapılan davranışlardır. Katılımcılar öğretmene karşı gelme ve küfür etme, öğretmenle dalga geçme gibi davranışların sıklıkla yaşandığını dile getirmişlerdir. Bazı öğrenciler öğretmenlere yapılan istenmeyen davranışların 
öğretmenlerin anlayış göstermemesinden kaynaklandığını ifade etmişlerdir. Okul içi iletişimin yetersiz olması bu tür sorunların da yaşanmasına zemin hazırlamaktadır. Öğretmenlerin sınıf içinde öğrencilerle iletişim halinde olmaları sınıf atmosferinin olumlu yönde gelişmesinde etkili olacağı gibi birçok sorunun da azalmasına, öğrencilerin psiko-sosyal, akademik ve duygusal olarak da gelişmesini sağlayacaktır (Işgıngöz ve Bülbül, 2012). Benzer şekilde Toytok ve Yıldırım'ın (2018) meslek liselerindeki çalışmasında da arkadaşlarına kötü muamelede bulunmak, öğretmene saygısızlık, sigara içmek veya bulundurmak ve dersin akışını bozma davranışlarının sıklıkla yaşandığı belirlenmiştir.

Katılımcılar devamsızlık ve okul terkinin 9. sınıfta yaşandığı konusunda ortak bir yargıya sahiptirler. Dokuzuncu sınıf eleme aşaması olarak nitelendirilmiştir. Devamsızlık ve okul terki geçiş aşamalarında yaşanabilecek uyum sorunları nedeniyle öğrencilerin okula aidiyet oluşturamamalarından kaynaklanmış olabilir. MEB'in 2018 Yılı Performans Programı'na göre mesleki ve teknik ortaöğretimde devamsızlık oranının diğer okul türlerine ve kademelerine göre daha yüksek olduğu dile getirilmiştir. Bu verilere göre mesleki ve teknik liseler \%39.9 ile ilk sırada yer almaktadır. Bülbül ve Toker-Gökçe (2015) meslek lisesi öğrencilerinin okula yönelik algılarını metaforlar aracılığı ile belirlemeyi amaçladıkları araştırmalarında da meslek lisesi ögrencilerinin büyük kısmının okulu disiplinli ve otoriter bir ortam olarak gördüklerini belirtmişlerdir. Aynı araştırmada öğrenciler okulu ifade etmede "hapishane" metaforunu sıklıkla kullanmışlardır.

Araştırmada eğitimciler devamsızlık ve okul terkine neden olan etmenler konusunda aile içi problemler ve sosyo-ekonomik faktörlere dikkati çekerken, öğrenciler bunların yanında akran etkisine de dikkati çekmişlerdir. Bir başka araştırmada da (Taş, Bora, Seviltopu ve Demirkaya, 2013) öğretmenler ile akranların tutum ve davranışlarının okul terk riski olan öğrenciler üzerinde önemli etkisi olduğu dile getirilmiştir. Karatepe'nin (2016) de vurguladığı gibi iyi bir eğitim ve gelecek imkânı ayrıcalıklı grupların lehine artarken dezavantajılı grupların ise aleyhine azalmaktadır. Öğrencilerin gelir elde edebilmek için okul saatlerinde çalışmak zorunda olması okula gelebilecek maddi imkânının olmaması ve kısa yoldan gelir elde etmek zorunda olması okulu ikinci plana itebilmektedir. Öğrencilerin devamsızlık ve okul terki davranışlarının kaynağı büyük oranda ailelerin çocuklarına karşı duyarlı olamayışları ve bu ailelerin karşılaştıkları ekonomik zorluklar ile okullardaki olanakların yetersizliğidir (Aküzüm, Yavaş, Tan ve Uçar, 2015). Benzer şekilde Bülbül'ün (2012) çalışmasında ise öğrencilerin ve öğretim üyelerinin okul terki nedenleri olarak akademik uyum sorunları ve maddi sıkıntılar üzerinde sıklıkla durdukları görülmüştür. Dolayısıyla yapılan diğer araştırmalarda da okul terk ve devamsızlığın ortak nedeninin sosyo-ekonomik faktörler olduğu görülmektedir. Ayrıca erken yaşta evlilikten dolayı da okulu bırakmak zorunda öğrencilerin olduğu dile getirilmiştir. Katılımcıların ifade ettiği gibi bazı öğrenciler aile içi problemlerin ve akran etkisiyle evliliği bir kurtuluş ya da bir kaçış olarak görebilmektedirler.

Devamsızlık ve okul terkini önleme noktasında katılımcıların vurgusu okula aidiyetin zayıf olmasıdır. Okulda yapılacak sosyal etkinlikler, ders saatleri ve eğitim programına yönelik düzenlemeler ve okul-aile işbirliğinin arttırılması ile öğrencilerin okula olan bağlılıkları güçlenecektir. Bu bulgular devamsızlık ve okul terkinin nedenleri ve öğrenci özellikleri konusundaki araştırma sonuçlarıyla örtüşmektedir.

Disiplin sorunlarının çözümünde alınacak önlemler kadar eğitimcilerin disiplin anlayışları da çok önemli yer tutmaktadır. Eğitimciler genel olarak öğrencilerin içinde bulundukları şartlardan dolayı disiplin dışı hareket etmelerini doğal karşıladıklarını dile getirmişlerdir. Benzer şekilde Çalışkan-Maya (2004) araştırmasında mesleki-teknik liselerde istenmeyen öğrenci davranışlarında öğretmenlerin öncelikli olarak disipline gönderme ve azarlama yolunu tercih ettiği sonucuna ulaşmıştır. Diğer taraftan cezanın çözüm olmadığını ödüllendirmenin daha etkili olduğunu söylemişlerdir. Benzer şekilde bazı öğrenciler cezanın etkili olduğunu ifade ederken bazıları ise cezanın çözüm getirmediğini söylemişlerdir. Öğrencilerin bu konudaki ifadeleri istenmeyen davranışların cezalandırılmasından rahatsız olmadıklarını da göstermektedir. Öğrencilerin cezaya ilişkin yargılarının istenmeyen davranışlarda aile ve toplumsal çevrenin ceza vererek çözüm üretme yaklaşımlarını içselleştirdiklerini gösterir. Eğitimcilerin ve öğrencilerin disiplin konusundaki görüş farklılıkları bazı çalışmalarda da rastlanmaktadır. Sarpkaya (2015) istenmeyen davranışlara ilişkin yaklaşımları ele aldığı çalışmada öğretmen ve yöneticilerde genel olarak yapıcı öneriler daha fazla iken, öğrenciler ve velilerde ceza ağırlıklı önerilerin daha fazla olduğu belirlenmiştir. İşgingöz ve Bülbül'ün (2012) araştırma sonuçlarına 
göre okul yöneticileri okulda diyalogun eğitim-öğretim etkinliklerine birçok katkısının olacağını düşünmektedirler. Yöneticiler diyaloğun okulda sıklıkla yaşanan şiddet, çeteleşme, gruplaşma olaylarının çözümüne, öğrenci başarısının artırılmasına, okuldaki ekip çalışmasını, işbirliğini, verimliliği arttırmaya, eğitim ortamının demokratikleşmesine, okul kültürünü oluşturmaya, okula bağlılığı artırmaya ve öğrencilerin kişilik gelişimine olumlu katkı sağlayacağını düşünmektedirler.

Bu çalışmanın bulgularına dayalı olarak şu sonuçlara ulaşılabilir:

Araştırmanın en önemli sonucu belirli toplumsal köken özelliklerinin yaygın gözlendiği iki okulda yaşanan istenmeyen davranışların, istenmeyen davranışların ele alındığ sonuçlarıyla tutarlığıdır. Araştırmada dezavantajlı toplumsal özelliklere sahip öğrencilerin okula aidiyet duyguları zayıf olduğu gibi okul terki ve okula devamsızlık oranı da yüksektir. Bunun nedenleri içinde özellikle alt toplumsal sınıftan gelen çocukların okula uyum sağlama güçlükleri çekmeleri ve eğitimin onlara kazandırabileceklerinin fazla olmadığına ilişkin kanaatleridir. Bu bakımdan okuldan beklentileri düşük ve davranışlarını sınırlamakta isteksiz olmaktadırlar. Okulu genel olarak sıkıcı ve sınırlandırıcı bir alan olarak görmektedirler. Bu da istenmeyen davranışların en önemli kaynağı olarak görülmüştür. Bir başka ifadeyle "istenmeyen yerlerde, istenmeyen davranışlarda" artış olmaktadır.

Bir diğer sonuç, öğrencilerin ailelerinden aldıkları ekonomik ve kültürel desteklerinin az olması kadar çocuklarından özellikle ekonomik destek beklentisi içinde olmalarıdır. Bu dezavantajlı toplumsal grupların genel bir eğilimidir. Bu da öğrencilerin okulu benimsemelerini olumsuz etkilerken okul dışındaki yaşama yönlendirmektedir.

Genel olarak araştırma bulguları alt sosyo-ekonomik çevreden gelen öğrencilerin oluşturduğu meslek liselerinde toplumsal yeniden üretimin eğitim yoluyla devam ettiğini göstermektedir. Öğrencilerin ailelerinden aldıkları ekonomik, kültürel ve eğitimsel sermaye okula ilişkin algı ve davranışlarında kendini göstermektedir. Okula ilgisizlik, iletişim sorunlarından kaynaklı şiddet olayları, madde kullanımı, akranlara yönelik şiddet, okula devamsızlık ve okul terki oranının yüksekliği, eğitim kazanımlarının sınırlığına yol açtığı gibi, düşük statülü meslek ve işlerde çalışmayı bir seçenek olarak gördükleri veya farkında olmadan razı oldukları anlaşılmaktadır. Bir başka ifadeyle meslek lisesi programlarının sağlayabileceği bir hayat tarzı ve standardının düşük olması ile öğrencilerin okullarındaki davranışlarının ve ilgilerinin standardının düşük olması toplumsal yeniden üretim bağlamında anlaşılabilir bir tutarlık olarak görülmektedir.

$\mathrm{Bu}$ bakımdan öğrencilerin istenmeyen davranışlarının büyük ölçüde toplumsal köken özellikleriyle ilişkili olması, çözümünün okul içinden çok okul dışındaki toplumsal, kültürel ve büyük ölçüde ekonomik ve politik yapılarda aranması gerektiği söylenebilir.

Özellikle devamsızlığın 9. sınıfta yaşanan bir sorun olduğu görülmektedir. Okulların öğrencilere yönelik etkili oryantasyon çalışmalarının yapılmasının da devamsızlık ve okul terkinin çözülmesinde katkısı olacaktır. Diğer taraftan devamsızlık diğer sinıflarda da devam etmekte ve sonu okul terkine kadar gittiği ve bunun en büyük kaynağının okula aidiyet duygusu eksikliği olmaktadır. Bu nedenle de özellikle öğrencileri okula bağlayacak sosyal etkinliklerin yapılması, öğrencilerin ilgisini çekecek farklı sosyal ortamların okul içinde oluşturulması öğrencilerin okulu daha çok benimsemesini sağlayacaktır. 


\section{Kaynakça}

Akpınar, B. ve Özdaş, F. (2013). Lise disiplin sorunlarının cinsiyet değişkeni açısından incelenmesi. Dicle Üniversitesi Ziya Gökalp Ĕ̈itim Fakültesi Dergisi, 21, 20-29.

Aküzüm, C., Yavaş, T. ve Uçar, M. B. (2015). İlköğretim kurumu öğrencilerinin devamsızlık ve okul terki nedenleri. Uşak Üniversitesi Sosyal Bilimler, 22.

Aldermen, T. (2001). In good discipline one size doesn’t fit all the education digest. Erişim adresi: http://web.b.ebscohost.com

Arıcak, T. (2011). Sınıf yönetimi. Gürsel, M. (Yay. haz.). Sını İçi Disiplin içinde (ss. 211-233). Konya: Eğitim Akademi Yayınları.

Arıcak, T. (2005). A systematic approach model in diagnosing and solving discipline problems in classroom. 27. ISPA Kolokyumu, Atina Üniversitesi. Erişim adresi: http://eric.ed.gov

Başar, H. (2003). Sinıf yönetimi (10. Baskı). Ankara: Anı Yayıncılık.

Başar, H. (2007). Sinıf yönetimi ögretmen el kitabl. Ankara: Morpa Kültür Yayınları.

Biber, K. (2003). İlköğretim birinci sınıf öğrencilerinin, ailelerinin sosyo-ekonomik düzeylerine göre öğretmen-aile iletişimi. Kuram ve Uygulamada Ĕ̆itim Yönetimi, 35, 360-373.

Bilir, A., Kuru, S. ve Tezcan, F. (2007). Muğla ili ortaöğretim okullarında disiplin uygulamalarına ilişkin yönetici ve öğretmen görüşleri. Muğla Üniversitesi Sosyal Bilimler Enstitüsü Dergisi, 19, 1-15.

Bourdieu, P. ve Passeron, J. C. (2015a). Yeniden üretim. Ĕgitim sistemine ilişkin bir teorinin ilkeleri. (A. Sümer, Ö. Akkaya ve L. Ünsald, Çev.). İstanbul: Heretik Yayınları.

Bourdieu, P. ve Passeron, J. C. (2015b). Varisler. Ögrrenciler ve kültür. (A. Sümer ve L. Ünsaldı, Çev.). İstanbul: Heretik Yayınları.

Bowles, S. (1999). Eşitsiz eğitim ve toplumsal işbölümünün yeniden üretimi. (K. İnal, Çev.). Eğitim ve Yaşam, 13, 14-18.

Bozdoğan, Z. (2004). Etkili öğretmenlik ĕgitimi (1. Basım). Ankara: Nobel Yayın Dağıtım.

Buyruk, H. (2009). Yükseköğretime geçiş sorunsalı. Eğitim Bilim Toplum Dergisi, 26, 69-88.

Bülbül, T. (2012). Yükseköğretimde okul terki: Nedenler ve çözümler. Eğitim ve Bilim, 37(166), 219235.

Bülbül, T. ve Toker-Gökçe, A. (2015). Meslek lisesi öğrencilerinin metaforik okul algıları: işlevselci bir yaklaşım. Ahi Evran Üniversitesi Kırşehir Eğitim Fakültesi Dergisi, 16(2), 273-291.

Celep, C. (2000). Sinıf yönetimi ve disiplini. Ankara: Anı Yayınc1lı.

Cemaloğlu, N. (2007). Disiplin ile ilgili kavramlar, ilkeler ve uygulamalar. Milli Eğitim, 175, 8-24.

Çalışkan-Maya, İ. (2004). Mesleki-Teknik Liselerde istenmeyen öğrenci davranışlarına gösterilen öğretmen tepkileri. XIII. Ulusal Eğitim Bilimleri Kurultayı 6-9 Temmuz 2004 İnönü Üniversitesi Eğitim Fakültesi, Malatya. Erişim adresi: https://pegem.net/dosyalar/dokuman.

Çetin, H. (2001). Devlet, ideoloji ve eğitim. C.Ü. Sosyal Bilimler Dergisi, 25(2), 201-211.

Çiftçi, M. (2008). Disiplin cezası alan ve almayan lise ögrrencilerinin ahlaki yargı yetenekleri bilişsel çarpıtmaları ve empatik becerilerinin karşılaştırılması, (Yayımlanmamış doktora tezi). Atatürk Üniversitesi, Erzurum.

Demirtaş, H., Üstüner, M. ve Özer, N. (2007). Okul yönetiminde karşılaş1lan sorunların öğrenci ve okul ile ilgili değişkenler açısından incelenmesi. Kuram ve Uygulamada Eğitim Yönetimi Dergisi, 13(3), 421-455.

Düzgün, Ş. (2006). Eğitim sürecinde ana-babaların çocuklarına olan etkileri. Atatürk Üniversitesi Sosyal Bilimler Enstitüsü Dergisi, 8(2), 225-238.

Eggleton, T. (2001). Discipline in the schools. Educational Resourches Information Center (ERIC). Opinion Papers. Erişim adresi. https://files.eric.ed.gov/fulltext/ED451554.pdf.

Ercan, L. (2009). Sınıf yönetimi. Küçükahmet, L. (Yay. haz.). Sinıfta istenmeyen davranışların yönetimi içinde (ss. 199-200). Ankara: Pegem Akademi.

Erden, M. (2005). Sinıf yönetimi (1. Bask1). İstanbul: Epsilon Yayınc1lık.

Erkul, A. ve Dalgıç, G. (2014). Meslek lisesi öğretmenlerinin mesleki tükenmişlik düzeylerinin incelenmesi. Eğitim Bilimleri Araştırmaları Dergisi, 4(2), 1-18.

Erzurum, H. H. ve Kır, İ. (2011). İlköğretim öğretmenlerinin kullandıkları disiplin türleri. Mustafa Kemal Üniversitesi Sosyal Bilimler Enstitüsü Dergisi, 16, 271-285.

Eserpek, A. (1977). Eğitimin sosyo-ekonomik mobilitede etkinliğini sınırlandıran faktörler. Ankara Üniversitesi Eğitim Fakültesi Dergisi, 10(1-4), 153-167. 
Eskicumalı, A. (2003). Eğitim ve toplumsal değişme: Türkiye'nin değişim sürecinde eğitimin rolü, 1923-1946. Boğaziçi Üniversitesi Ĕ̈itim Dergisi. 19(2),15-29.

Fındık, L. Y. ve Kavak, Y. (2013). Türkiye'deki sosyo-ekonomik açıdan dezavantajlı öğrencilerin PISA 2009 başarılarının değerlendirilmesi. Kuram ve Uygulamada Eğitim Yönetimi, 2(2), 249-273.

Foucault, M. (1992). Hapishanenin doğuşu (1. Baskı). (M. A. Kılıçbay, Çev.). Ankara: İmge Yayıncılık. Gordon, T. (2000). Çocukta dış disiplin mi? İç disiplin mi? ( E. Aksay, Çev). Ankara: Sistem Yayıncılık. Gürol, D. T. (2008). Madde bağımlılığı açısından riskli adolesanlar. Sempozyum Dizisi, 63, 65-68.

Gürsel, M. (2012). Türk eğitim sistemi ve okul yönetimi. Kavramlar, süreçler ve uygulamalar. Konya: Eğitim Akademi Yayınevi.

İşginöz, R. ve Bülbül, T. (2012). Okulda diyalog: Okul yönetiminin rolü. Eğitim Bilimleri Araştırmaları Dergisi, 2(1), 125-146.

İpek, Ö. (2012). Foucault'nun disiplin toplumu kavramının ıslah kurumları aracıllğıyla yeniden üretimi: Frederick Wiseman belgeselleri örneği (Yayımlanmamış Yüksek Lisans Tezi). İstanbul Üniversitesi, İstanbul.

Karataş, Z. (2008). Lise öğrencilerinin suçluluk ve utanç puanlarının disiplin cezası alıp almama ve cinsiyetleri açısından incelenmesi. Mersin Üniversitesi Ĕ̆itim Fakültesi Dergisi, 2, 103-114.

Karatepe, R. (2016). İlkokul ve ortaokul yöneticilerinin okullarındaki yönetsel uygulamalarını bankacı eğitim modeli çerçevesinde değerlendirilmesi (Yayımlanmamış Yüksek Lisans Tezi). Mersin Üniversitesi Eğitim Bilimleri Enstitüsü, Mersin.

Kılıç, D. Ö. (2009). İlköğretim okulu öğretmenlerinin okullarındaki disiplin anlayışına ilişkin görüşleri (Yayımlanmamış yüksek lisans tezi). Mersin Üniversitesi Eğitim Bilimleri Enstitüsü, Mersin.

Kök, M. (2007). Ortaöğretim kurumlarındaki ögretmen, rehber ögretmen ve yöneticilerin ortaöğretim kurumları ödül ve disiplin yönetmeliğindeki ceza gerektiren davranışlar ile cezalara ilişkin görüşleri (Yayımlanmamış Doktora Tezi). Hacettepe Üniversitesi Eğitim Bilimleri Enstitüsü, Ankara.

Kuş, Z. ve Karatekin, K. (2009). Öğrencilerin okul ortamında kurallara uygun davranma yeterliklerinin çeşitli değişkenler açısından incelenmesi. Ahi Evran Üniversitesi Kırşehir Eğitim Fakültesi Dergisi, 10(1), 183-196.

Milli Eğitim Bakanlığı (MEB). (2018). 2018 y1lı performans programı. Erişim adresi: http://sgb.meb.gov.tr/meb_iys_dosyalar/2018_03/19144448_2018_PP_-_13.02.2017_2.pdf

Özsöz, C. (2014). Pierre Bourdiue: Simgesel şiddet, eğitim, iktidar. Cogito Üç aylık Düşünce Dergisi, 76, 290-311.

Öztürk, B. (2004). Sınıf yönetimi. E. Karip (Yay. haz.). Sinıfta İstenmeyen Davranışların Önlenmesi ve Giderilmesi içinde (ss. 130-132) içinde. Ankara: PegemA Yayınc1lık.

Ritchie, J. ve Lewis, J. (2013). Qualitative research practice: A guide for social science students and researcher. New Delhi: Sage.

Sarıbaş, S. ve Babadağ, G. (2015). Temel eğitimin temel sorunları. Anadolu Ĕ̆itim Liderliği ve Öğretim Dergisi, 3(1), 18-34.

Sarpkaya, P. (2007). Yönetici, öğretmen, öğrenci ve velilere göre resmi liselerdeki öğrenci disiplin sorunlarının nedenleri. Pamukkale Üniversitesi Ĕ̆itim Fakültesi Dergisi, 22, 110-121.

Taş, A., Bora, V., Seviltopu, A. ve Demirkaya, Y. (2013). Meslek lisesi öğrencilerini okul terk nedenleri. Kuram ve Uygulamada Eğitim Bilimleri, 13(3), 1551-1566.

Temir, R. (2013). M. Foucault'un disipliner iktidar bağlamında gizli müfredat ve disiplin üzerine bir araştırma: Sait Sabri Ağaoğlu Anadolu Lisesi örneği (Yayımlanmamış Yüksek Lisans Tezi). Uşak Üniversitesi, Uşak.

Thrupp, M. (1998). Exploring the Politics of Blame: school inspection and its contestation in New Zealandand England. Comparative Education, 34, 195-208.

Toytok, E. H. ve Yıldırım, M. B. (2018). Meslek liselerinde disiplin sorunları ve nedenleri. Abant İzzet Baysal Üniversitesi Ë̆itim Fakültesi Dergisi, 18(3),1759-1778.

Tunç, B. (2011). Yükseköğretimde teknik eğitim fakültesi tercihinin sosyo-ekonomik kökenlerine iliş̧in bir inceleme: Tarsus Teknik Eğitim Fakültesi örneği. Kuram ve Uygulamada Eğitim Bilimleri, 11(4), 1929-1942.

Tunç, B., Yıldız, S. ve Doğan, A. (2015). Meslek liselerinde disiplin sorunları, nedenleri ve çözümü bir durum analizi. Abant İzzet Baysal Üniversitesi Ë̆itim Fakültesi Dergisi, 15(2), 384-403. 
Vuranok, T. T., Özcan, M. ve Çelebi, N. (2017). Mesleki ve genel lise öğrencilerinin sosyo-ekonomik statüsü (İstanbul Avrupa Yakası Örneği). E. Babaoğlan, E. Kıral, A. Çilek ve F. Güçlü Yılmaz (Yay. haz.). Eğitime Farklı Bakış içinde (ss. 177-188). Ankara. EYUDER Yayınları.

Vurucu, F. (2010). Meslek lisesi ögrrencilerinin meslek seçimi yeterliliği ve meslek seçimini etkileyen faktörler (Yayımlanmamış Yüksek Lisans Tezi). Yeditepe Üniversitesi Sosyal Bilimleri Enstitüsü, istanbul.

Yıldıım, İ. (2010). Sinıf içi disiplin sorunları ile anababa tutumları arasındaki ilişki (Yayımlanmamış Yüksek Lisans Tezi). Atatürk Üniversitesi Eğitim Bilimleri Enstitüsü, Erzurum. 


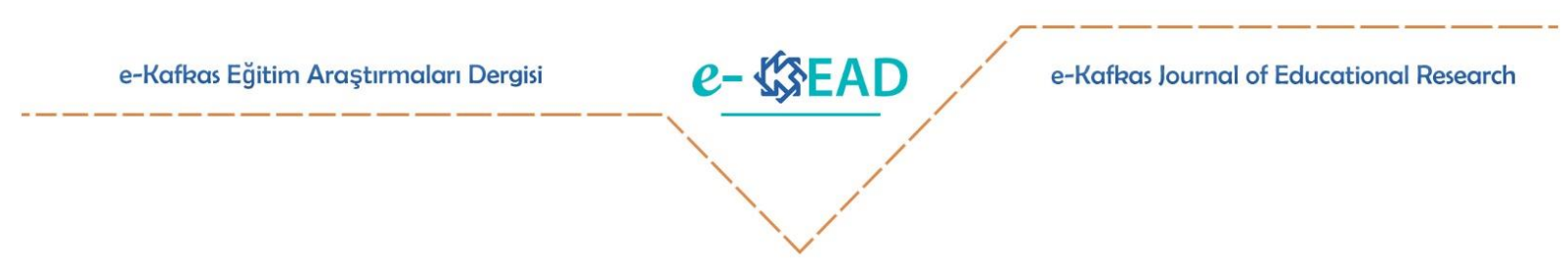

\section{Social Origin Characteristics and Undesirable Behaviors of Students: A Situation Analysis in Vocational High Schools}

\section{Hayriye Yeşil Aydoğan}

Binali Tunç

To cite this article: Aydoğan, Y. A. ve Tunç, B. (2020). Öğrencilerin toplumsal köken özellikleri ve istenmeyen davranışlar: Meslek liselerinde bir durum analizi. e- Kafkas Eğitim Araşstırmaları Dergisi, 7, 185-206. doi:10.30900/kafkasegt.750179

\section{Research article}

Received: 09.06.2020

Accepted: 21.07 .2020

\section{Introduction}

One of the first issues raised about education is "discipline". Studies on discipline show that although undesirable behaviors generally occur in all kinds of schools, they are relatively more experienced in vocational high schools. Researches show that vocational high schools are a type of school with low academic success and students comes from deprived families (Bülbül, 2012; Findık \& Kavak, 2013; Tunç, 2011; Tunç, Yıldız \& Doğan, 2015; Vuranok, Özcan \& Çelebi, 2017). While the social origin characteristics of vocational high school students are predominantly come from poor families, on the other hand, being the type of school where problematic behaviors are experienced the most, it indicates the connection between students' problematic behaviors and their social origins.

In the researches, while defining the undesired behaviors, their causes, and solution suggestions, the socio-economic dimensions are neglected. In other words, while the social dimensions of undesired behavior problems at school, the effect of the family and social environment on student behavior is neglected. Problem behaviors are relatively more common among students from disadvantaged environments and in schools in disadvantaged settlements (Tunç, Yıldız \& Doğan, 2015).

Despite the fact that the subject is handled with many variables, the limited number of studies on the relationship between problem behaviors and social origin makes it difficult to understand all aspects of the subject. The investigation of the socio-economic aspects of problem behaviors will transcend the issue in a social context, surpassing the traditional point of view that problem behavior is accepted as a phenomenon that begins at school and should be sought in school. It is thought that revealing the relationship between students 'social backgrounds and problem behaviors at school will make us realize that socio-economic factors also play a role in the basis of what we attribute as a discipline problem and that the educators' approach to students and their attitudes towards problem behaviors are considered.

\section{Method}

In this study, the social backgrounds of problem behaviors experienced in vocational high schools are tried to be understood. The research is organized in accordance with the qualitative research pattern since it aims to understand students' problem behaviors in terms of their socioeconomic origins (Ritchie \& Lewis, 2013). Three administrators, five subject-matter teachers, three guidance teachers, and 12 students were interviewed. Face-to-face interviews were conducted with semi-structured interview forms as the personal perspectives and experiences of the participants regarding the social origins of problem behaviors were tried to be understood (Ritchie \& Lewis, 2013).

Students generally come from socio-economically deprived families who live in the outskirts. Although the academic success level in both schools is low, the rate of students attending higher 
education is very low. Education levels of families are low, problems in the family are common, general farmers, diapers, etc. mostly work in temporary and precarious jobs. The parents of four students are secondary school graduates, while the parents of two students are primary school graduates, that is, the father of one student and the mother of another student are primary school graduates. Two students stated that one of their parents is illiterate. However, one of the parents of a student is a high school graduate. The research data were analyzed with a descriptive level content analysis technique in order to gather, organize, and interpret participant statements within the framework of certain concepts and themes (Yıldırım \& Şimşek, 2000).

\section{Conclusion}

In the research, students with disadvantaged social origin characteristics have a weak sense of commitment to school, and school dropout and absenteeism rates are high. The reasons for this are that, especially children from the lower social class have difficulties in adapting to school, they think that education is not much that they can gain. In this respect, their expectations from the school may be low and they are reluctant to limit their behavior at school. They see the school as a boring and restrictive area in general. This has been seen as the most important source of undesirable behaviors. In other words, there is an increase in "undesired behaviors". Students are especially expected to give economic support to their families. This is a general trend of disadvantaged social groups. While this negatively affects students' adoption of the school, it directs them to life outside.

Findings show that social reproduction continues through education in vocational high schools formed by students from the lower socio-economic environment. The economic, cultural, and educational transfer that students receive from their families is also reflected in students' perceptions and behaviors about school. It is understood that they see it as an option or unwittingly to consider working in low-status professions and jobs, as well as lack of interest in school, violent incidents due to communication problems, addictions, violence against peers, absenteeism and high school dropout rate, and limited educational achievements. In other words, a low standard of life and standard that vocational high school programs can provide, and the low standard of students' behavior and interests in schools are understandable in the context of social reproduction. In this respect, it can be said that students' undesirable behaviors are largely related to their social origin characteristics, and their solution should be sought in social, cultural, and mostly, economic and political structures outside the school.

Especially absenteeism seems to be a problem in 9th grade. The effective orientation of schools for students will also contribute to resolving absenteeism and dropout. On the other hand, absenteeism continues in other classes and the end of it goes until school dropout and the biggest source of this is the lack of sense of belonging to the school. For this reason, especially social activities that will connect students to the school and creating different social environments that will attract the students' attention will enable the students to adopt the school more. 